\title{
Unilateral Tariff Liberalisation*
}

\author{
Richard Baldwin $^{\dagger}$ \\ Graduate Institute, Geneva
}

\begin{abstract}
Unilateral tariff liberalisation by developing nations is pervasive but our understanding of it is shallow. This paper strives to partly redress this lacuna on the theory side by introducing three novel political economy mechanisms with particular emphasis on the role of production unbundling. One mechanism studies how lowering frictional barriers to imported parts can destroy the correlation of interests between parts producers and their downstream customers. A second mechanism studies how Kojima's pro-trade FDI raises the political economy cost of maintaining high upstream barriers. The third works via a general equilibrium channel whereby a developing country's participation in the supply chains of advanced-nation industries undermines their own competitiveness in final goods, thus making final good protection more politically costly. In essence, the argument is that developing nations' pursuit of the export-processing industrialisation undermines their infant-industry industrialisation strategies.
\end{abstract}

Keywords: Unilateral tariff liberalisation, race-to-the-bottom, political economy

JEL Classification: F1, F13, F15

\section{Introduction}

Trade liberalization for much of the second half of the 20th century was difficult (Zeiler 1997). It was slow, it involved only rich nations, and it occurred only in the context of reciprocal bargains - both GATT Rounds and Regional Trade Agreements (RTAs). The reciprocity was critical. Reciprocity means that foreign tariffs fall only if domestic tariffs do, so mercantilists lobby against protectionists in their own nation. This is why governments found it politically optimal to cut tariffs in reciprocal bargains that they had previously found optimal to impose

Received 12 September, 2010; received in revised form 22 November, 2010; accepted 23 November 2010.

* This paper was written for a special issue of The International Economy (the journal of the Japan Society of International Economics) in tribute to the late Professor Kiyoshi Kojima. As a great admirer of Professor Kojima's work and wisdom, I was honoured to be asked to help commemorate his life's work with this contribution. I would like to thank Caroline Freund, Paola Conconi, Bernard Hoekman, Pierre-Louis Vezina, Yose Damuri, Emanuel Ornelas, and an anonymous referee for helpful comments and suggestions that greatly improved the paper.

$\dagger$ Address for correspondence: Graduate Institute, Geneva. E-mail: richard.baldwin@graduateinstitute.ch 


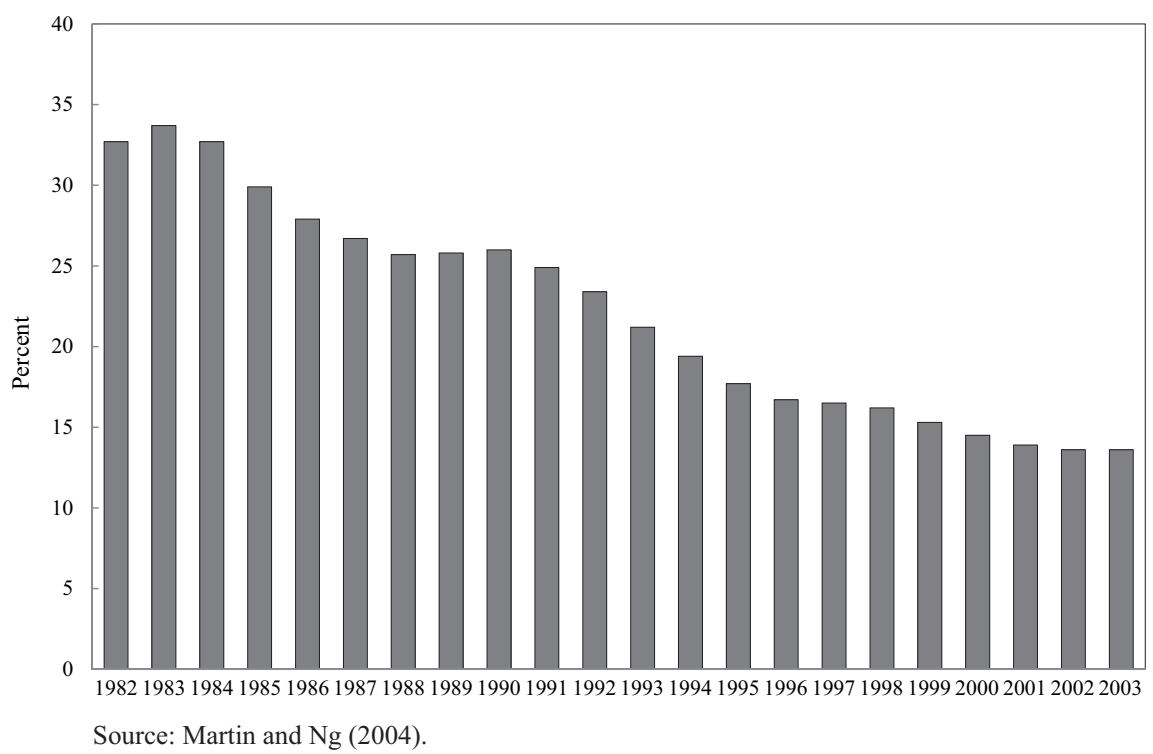

Figure 1 Evolution of average tariff rates in developing nations.

(Moser 1990).

In the late 1980s, this situation changed. Many nations that had previously eschewed all forms of liberalization began to cut their tariffs autonomously. The World Bank, for instance, estimates that developing nations unilaterally lowered their average tariffs by something like 14 percentage points between 1983 and 2003 independently of GATT rounds and RTAs (Martin and Ng 2004). The evolution of these tariff cuts is illustrated in Figure 1. This shows the path of average developing nation tariffs (three year moving average) from 1982 to 2003. While some nations lowered their tariffs starting in mid 1980s, most did the bulk of their tariff cutting in the mid to late 1990s. Note that unilateral liberalisation has been especially marked in parts and components.

The rise of unilateralism occurred at approximately the same time as a phenomenon known variously as fragmentation, production unbundling, vertical specialisation, or internationalisation of the supply chain (Kimura et al 2007, Campa and Goldberg 1997).

Due to the revolution in information and communication technologies (ICT) - see Figure 2 - it became feasible to organize complex manufacturing activity among spatially separated facilities - what I called "the second unbundling" in Baldwin (2006a). As the factor intensity of manufacturing stages can vary greatly within a single production process, and factor prices variable greatly across nations, the ability to spatially unbundle the process opened the door to a new type of vertically specialised trade. Trade in parts and components flourished as richcountry manufacturers offshored labour-intensive stages to emerging economies. This first occurred in the mid1980s across the US-Mexico border (Hanson and Feenstra 1997) where the phenomenon is known as maquiladora trade, and, simultaneously, within East Asia where it is known as Factory Asia (Ando and Kimura 2005).

This paper is an effort to understand the political economy of unilateral liberalization and - in particular - its association with the ICT revolution and production unbundling; plainly this cannot account for all the unilateralism 


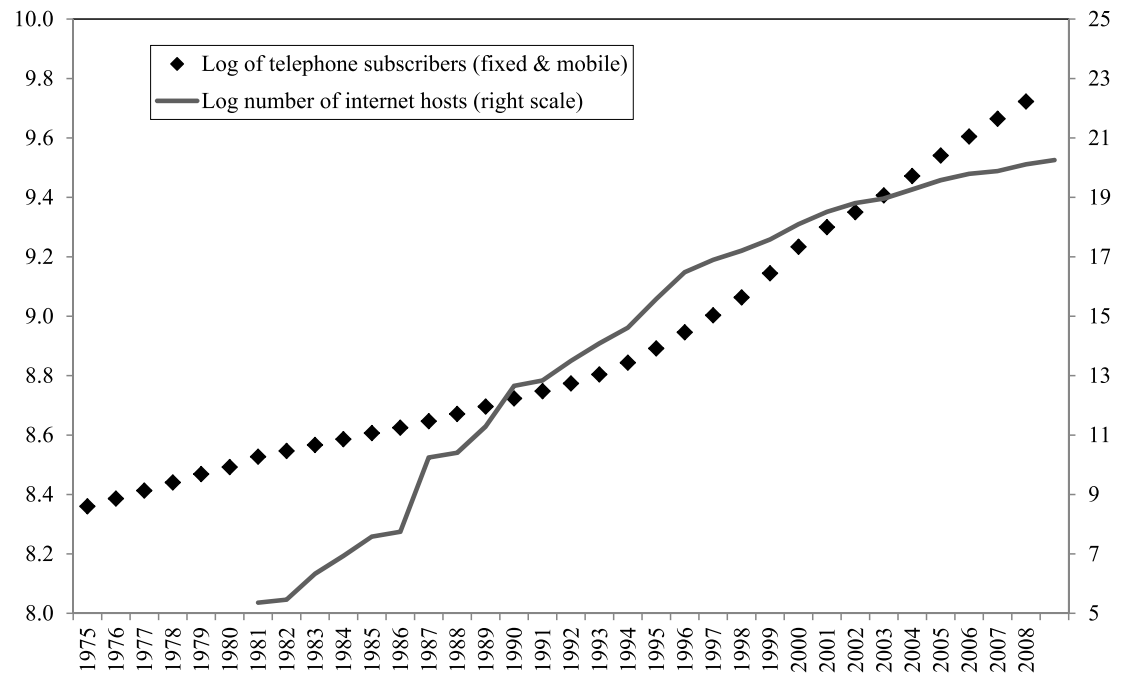

Sources: World Bank, Doing Business database, and www.isc.o rg/solutions/survey/history.

Figure 2 ICT revolution indicators

and the stories work best for trade among the members of what has been called 'Factory Asia', and by extension trade among the members of Factory North America, and Factory Europe. Specifically, the paper presents three novel mechanisms that can account for unilateral liberalisation of tariffs that occurs in tandem with production unbundling. The three mechanisms turn on the two main facets of production unbundling - trade and investment. The trade element is reflected in the growth of trade in parts and components. The investment element is reflected in the offshoring of labour-intensive segments of the value chain, or what Kiyoshi Kojima called "pro-trade FDI" (Kojima 1977).

\section{Unilateral liberalisation and Kojima's pro-trade FDI}

The first mechanism takes as its point of departure the assumption that the developing country government is a 'development state', i.e. interested in industrialisation per se. If the weight the government applies to industrialisation versus general welfare is high enough, the initial situation is one of high tariff barriers on final manufactured goods as well as their parts and components - i.e. a policy of infant industry protection.

This starting point is meant to represent the 1960s and 1970s when industries in both developed and developing nations were highly clustered spatially, often in a particular city. The reason for this spatial concentration was simple; the costs of coordinating complex processes like manufacturing were greatly reduced by physical proximity.

As the ICT technology improved, communication and coordination at distance became cheaper and more reliable. This made it economically feasible to offshore manufacturing from high-wage-high-technology nations to low-wage-low-technology nations while ensuring that the dispersed supply chain worked as a whole. In essence, the various 'production bays' in the old style factories were unbundled and relocated to nations with 
lower production costs. For example instead of using Japanese workers for all stages of production, the labour intensive stages could be located in labour-abundant nations. The ICT improvements and improved reliability of transportation links meant that this could be done with a minimum disruption to the manufacturing stages that remained in Japan.

From the perspective of developing nations - especially those geographically close to industrial powerhouse nations like Japan, the US and Germany - this opened a new pathway to industrialisation. Rather than developing domestic capacities over a span of decades (as was done in the US, Germany, Japan, Korea and others) offshoring allowed nations like Thailand and the Philippines to set up sophisticated manufacturing facilities in a matter of months, or years.

It is important to note, that the big change here was not transportation costs but rather what might be called 'coordination costs', i.e. the sort of costs that led to the clustering of manufacturing processes within a single factory, or within a single industrial zone or region. This is relevant since there is little evidence that the world experienced a sharp reduction in shipping costs after the 1970s (Hummels 1999). The focus here is on costs that are critical to complex organisational problems such as the manufacture of a car or a sophisticated electronic device. Particularly crucial in such activities is low-cost and highly reliable telecommunication, and lower costs and more reliable coordination due to the spread of personal computers and business software packages. The rise of lowercost and more reliable air cargo services and express mail are other changes of the same ilk. At the same time, air travel networks became denser and in some case airfares fell, thereby facilitating the short-term movement of managers and technicians between offshored factories. ${ }^{1)}$

In the model, this new form of industrialisation changes the political economy problem facing the developing nation government. The shock is that the 'pro-trade FDI' shifts the developing nation's comparative advantage; the nation switches from being an importer (or potential importer if tariffs were prohibitive) to being an exporter of the product concerned - be it a part, component, or final good. In addition to directly rendering import tariffs on the newly exported good useless, the new production shifts the government's view on upstream tariffs. Protection of upstream inputs always harms downstream production, but the newly established factory expands the marginal cost of any given upstream tariff. Thus whatever the optimal tariff was on parts before the offshoring, it becomes lower in response to the pro-trade FDI. In this way, pro-trade FDI fosters unilateral liberalisation by developing nations. A slight twist on this - so-called race-to-the-bottom unilateralism - considers the possibility that the multinational establishing the new factory may have a variety of location choices and so may bargain for a zero tariff on upstream inputs (Baldwin 2006b).

One reaction to this change could be more nuanced than a lowering of the MFN applied tariff. Governments could - and many did - set up export processing zones where tariffs in imported parts were low or zero (or else they operated a scheme of duty drawback). This would allow the nation to both exploit the new industrialisation opportunities offered by pro-trade FDI while simultaneously maintaining high infant-industry tariffs for production

1) See Ariu and Mion (2010) for evidence on the link between ICT and offshoring. 
destined for the domestic market. We return to this point in the third mechanism.

\section{Infant industry protection and production unbundling}

The second model of unilateral tariff liberalisation focuses on trade in parts and components per se - abstracting from offshore investment by high-technology nations. The developing country government in this model is assumed to be of the Grossman-Helpman "Protection for Sale" (PFS) type (Grossman and Helpman 1994).

In this sort of political economy setting, a positive tariff on imported intermediates is politically optimal only if the protection somehow lowers the local cost of the intermediates. The point is that price-rising protection of upstream segments of the production chain is worse than a zero-sum game when it comes to profits (and thus political contributions in the PFS set up). Given that the government cares about the sum of contributions and this is tied to the sum of profits, the optimal upstream tariff is zero (see Cadot, de Melo and Olarreaga 2004).

To explain the presence of high tariffs on parts and components as well as final goods, we must work with an economic model where protection may lower local prices. One natural one is a model where infant-industry protection makes economic sense. The idea starts from the premise that parts production is subject to economies of scale so that local production is only economic if it takes place on a sufficiently large scale. This sets up a situation of multiple equilibria that is most naturally modelled as external economies of scale. Without a sufficiently high tariff on parts, there would be little domestic parts production and marginal production costs would be high forcing domestic final goods producers to import parts. Even if imported parts are cheaper in foreign nations, the presence of important frictional barriers (coordination, communication, etc.) means that importing parts is costly for final good producers in developing nations. In this situation, a tariff on parts can stimulate domestic production and thus actually lower the domestic costs of parts (as local production avoids the frictional barriers). In this setting, lobbying for a tariff on parts is lobbying for lower priced parts, not higher priced parts. For this reason, final goods producers and parts producers find their interests aligned initially and high tariffs on both are politically optimal. ${ }^{2)}$

Of course if the goal is to explain historical policy, all we need is that the government and final good producers believe that protection of parts will lower costs, we don't actually need the economics of infant-industry protection to make sense. Here it is worth noting that the efficacy of infant-industry protection was a mainstream belief in the 1950s, even if such faith is rare in the modern world. In the early days of the post-war trade system, the merits of industry-creating protection were regarded as clear cut. For example, the 1958 Haberler Commission which examined the problems of developing nations in the world trade system - summarises the pervasive belief in the need for and effectiveness of infant industry protection. We can see this belief in a contemporary review of the Report published in the Quarterly Journal of Economics. "Referring to the underdeveloped countries in a general way, the authors recognize that, in their case, special considerations justify a rather greater use of trade

2) The simple model in this paper focuses on one set of assumptions that generates infant-industry protection, but there are many more. For example there are several new economic geography models where protection lowers domestic prices by fostering an industrial cluster that would not have otherwise existed (Venables, 1985, 1987). 
controls and of protection than in the highly industrialized countries. Few economists will disagree with this view." (Richter 1959). Note that the Report reflected mainstream thinking. The authors comprised three of the most eminent trade economists of the time - Gottfried Haberler, James Meade and Jan Tinbergen - and it was commissioned by GATT members which included all the major Western powers and many developing nations. The Report's conclusions provided important intellectual underpinnings for the rather general exceptions that developing nations were granted in the GATT (Title IV) to refrain from making reciprocal tariff cuts in GATT Rounds.

Taking this economic model as given, the initial political equilibrium features high tariffs on both upstream and downstream goods. The trigger for unilateral tariff liberalisation is a drop in the frictional trade costs due to the ICT revolution. When these costs fall enough to make imported parts cheaper than locally made parts the correlation of interests between final and parts producers breaks down. When it does, full liberalisation of parts is the PFS equilibrium, at least if both parts and final goods makers are organised; more on this below. Note that the key in this model is the reduction in the frictional barriers to imported parts, not pro-trade FDI.

\section{The death of infant-industry industrialisation strategies}

As mentioned, pro-trade FDI need not result in the removal of infant industry tariffs directly if the government can segment imports between domestic-oriented production and export-oriented production. The third mechanism introduced in this paper combines the first two in a way that explains the demise of government's faith in infant industry protection. The basic story is simple.

In the 1960s and 1970s, many developing nations (especially in East Asia) pursued dual track industrialisation strategies (Ando and Kimura 2005). The first track was import substitution that encouraged the development of the full supply chain behind tariff barriers. The second track was to encourage export processing activities where the nation's low-cost labour was used by multinational corporations to lower the cost of their components. As the production unbundling proceeded and the offshoring of segments of the value added chain spread, the relative competitiveness of infant-industry goods was undermined. In essence, developing nations' participation in international supply chains undermined their own competitiveness in final goods.

To put it differently, observe that before unbundling, manufacturing involved a collection of labour intensive stages and knowledge intensive stages. This bundling tended to mute comparative advantages. Competitiveness of the, say, Japanese carmakers was hindered by the fact that labour-intensive stages had to be done by high-wage Japanese. When production unbundling became possible, the cost of the Japanese production fell since offshoring allowed Japan to borrow elements of developing nation's comparative advantage in labour-intensive activities. Importantly, this was not mutual. The developing nation automakers did not enjoy a corresponding 'borrowing' of the Japan's comparative advantage in knowledge-intensive stages. The net result is that production unbundling heightens the rich nation's comparative advantage in cars as its costs fall but the developing country carmaker's costs did not. 
As far as the mechanism is concerned, the key point is that the shift in competitiveness tended to raise the political economy cost of infant-industry protection in two ways. First, by lowering the world price of cars, offshoring raised the domestic welfare costs of any given level of final good production. The politically optimal response would be some lowering of final good protection. Second, if developing country car-markers hoped to maintain their competitiveness, they would have to purchase components from the lowest cost source rather than favouring local parts makers created by infant-industry policies. This increased political pressure to reduce tariffs on parts and components. To put it differently, maintaining the same rate of effective protection in the face of offshoring-induced drops in final-good world prices would require a reduction in upstream tariffs. As this process proceeds, maintenance of the same level of protection lead to a progressive hollowing out the infant-industry cluster, starting at the beginning the supply chain and working down towards the final good. In the extreme, the only thing that 'infant industry' protection can salvage is the assembling of 'knock-down kits' (i.e. imported kits that contain all the necessary parts and components to make the final automobile). At this point, faith in the eventual maturation of infant industry may be fatally eroded with the result that the nation decides to turn itself into one big export processing zone rather than attempt to maintain the infant-industry track of dual-track development.

\subsection{Plan of the paper}

As it turns out, the particular modelling choices for the three mechanisms make it more convenient to address the second mechanism first, followed by the first and then the third. Before turning to the new theory, the next section, Section 2, extensively reviews the existing literature to situate this paper's contribution into the ongoing effort to understand the political economy of unilateral tariff liberalisation. After that Section 3 introduces basic issues by working through a protection-for-sale (PFS) political economy model in the presence of a simple supply chain. Section 4 presents the two basic models, and the subsequent section discusses a number of obvious extension and combinations of the two that may account for various aspects of the observed liberalisation. The penultimate section sketches out a model of the 'death of dual track development' and the final section present some concluding remarks. 


\section{Literature Review}

The political economy logic of reciprocal liberalisation is well understood. ${ }^{3)}$ Reciprocity harnesses mercantilist interests in each nation to the task of lobbying against protectionists - a political economy realignment that makes it optimal for governments to remove tariffs that they previously found optimal to impose. The process can continue due a 'juggernaut effect' whereby tariff cuts strengthen exporters and weaken import competitors in all nations, so that after a few years of industrial adjustment, governments once again find it optimal to cut tariffs that they found optimal to preserve in earlier reciprocal trade talks. ${ }^{4)}$ While this explains the key aspects of the GATT's tarifflowering success, it does not account for the facts in Figure 1. Reciprocity played no direct role in developing nations' unilateralism.

Given the pervasiveness of unilateralism, and the fact that it has been going on since the mid 1980s, there is remarkably little theoretical literature exploring the political economy of unilateral trade liberalization. Before discussing the existing works, it is important to note that some explanation is required. Tariff liberalisation is a situation where a government finds it politically optimal to remove a tariff that it previously found optimal to impose. Any complete model of unilateralism requires three elements: an explanation of why protection was politically optimal in the first place, a shock that changes the political and/or economic setting, and an explanation of why the shock makes a lower tariff politically optimal (Baldwin and Baldwin 1996). Arguing that governments removed tariffs because they finally understood that free trade was in their nation's own best interest is insufficient as one then must explain why governments failed to understand this previously.

In the economics literature, most discussions of unilateralism consist of practical accounts of how and why various nations undertook such measures (e.g. Garnaut 1991, Young 1996, Edwards and Lederman 1998, Richardson 2001, and Sally 2008). The political economy theories that account for unilateralism include Coates and Ludema (2001), Krishna and Mitra (2008), and very recently Ludema, Mayda and Mishra (2010), and Conconi and Perroni (2010). Ethier (2002) presents a model of unilateral protection (so-called aggressive unilateralism) but his model does not work in reverse to explain unilateral tariff cutting.

3) As Cooper (1971 p.410) puts it: "The principle of reciprocity is designed to hold out the promise of export gains to certain sectors of the economy, and thereby to establish a counterweight to those who will be hurt by increased imports. Reciprocity attempts to build pluralistic support for tariff reduction." Well known to trade negotiators, this point was surely not novel to Cooper and many have made it subsequently including Roesseler (1978), Blackhurst (1979), and Baldwin (1980). For an early formal treatment see Moser (1990), or Hillman and Moser (1992); the basic logic of these early papers were brought to the attention of the broad community of trade academics via the PFS parameterisation introduced by Grossman and Helpman (1995).

4) The juggernaut effect, i.e. the idea that initial tariff cuts trigger a second round of cuts after industrial adjustment, is due to Baldwin (1994 p. 73); Baldwin and Robert-Nicoud (2008) provide a mathematical treatment. Baldwin (2010) uses the framework to structure the historical narrative of the GATT's 50 years of tariff cutting success. Empirical support can be found in Fugazza and Robert-Nicoud (2010). 
Coates and Ludema (2001) work in the tradition that borrows industrial organisation models of collusion between firms, relabeling the firms as nations, and cooperative price-setting as cooperative tariff-setting (see Dixit 1987 for an early example). Coates and Ludema (2001) borrow a set-up akin to the Porter and Green (1984) model of collusion with imperfect monitoring and uncertain demand where an unobservable shock may disturb what would otherwise be a standard dynamic game of collusion. Coates and Ludema (2001) assume that two nations sign a reciprocal tariff-cutting agreement the ratification of which is unsure in the short-run but $100 \%$ certain in the long run. Using a repeated game set-up, they show that the partner nation might unilaterally implement its side of the reciprocal agreement even if the other nation fails to ratify the agreement in the first period.

There are two main difficulties in using the Coates and Ludema (2001) model to structure our thinking about the late 1980s and 1990s unilateralism. First their model is about not really about unilateralism; it is about temporary unilateral implementation of a reciprocal trade agreement. Second, their model works in the 'self-enforcing' trade agreement tradition which is marred by a serious flaw when applied to tariff liberalisation. ${ }^{5}$ )

The flaw shows up even in the simplest 'self-enforcing' model. Define $\mathrm{W}^{\mathrm{c}}, \mathrm{W}^{\mathrm{n}}$, and $\mathrm{W}^{\mathrm{d}}$ as a nation's welfare when, respectively, the trade agreement is implemented ('c' being a mnemonic for cooperation), when all play is non-cooperative (' $n$ ' for Nash), and when the nation in question unilaterally deviates from the cooperative equilibrium ('d' for deviation). Under standard assumptions, the stage-game is a prisoners' dilemma, i.e. $\mathrm{W}^{\mathrm{d}}>$ $W^{\mathrm{c}}>W^{\mathrm{n}}$. Cooperation is sustained by the threat of a permanent revision to Wn the period after deviation is observed. Formally, the present value of cooperating forever, and of playing Nash forever after any deviation are, respectively, $\mathrm{W}^{\mathrm{c}} /(1-\delta)$ and $\delta \mathrm{W}^{\mathrm{c}} /(1-\delta)$, where $\delta$ equals $1 /(1+\rho)$ and $\rho$ is the discount rate. Price collusion in an industrial organisation model, and reciprocal tariff cutting in the self-enforcing trade agreement model works if and only if $\mathrm{W}^{\mathrm{c}}>(1-\delta) \mathrm{W}^{\mathrm{d}}+\delta \mathrm{W}^{\mathrm{n}}$. The maximum sustainable cooperation can be measured by $\mathrm{W}^{\mathrm{c}}-\mathrm{W}^{\mathrm{n}}$.

For any given annual discount rate, say 5\%, the key to this condition is the length of the period in which deviation can occur without retaliation. If a nation can maintain the high, deviation-tariff while others keep theirs at the cooperative level for, say a year, $\delta$ is about 0.95 ; if the deviation is detected and punished quickly, say after one day, then $\delta$ is 0.999863 . The maximum sustainable cooperation that can be explained by this approach - which is equal to $(1-\delta)\left(\mathrm{W}^{\mathrm{d}}-\mathrm{W}^{\mathrm{n}}\right)$ - limits to zero as the non-detection period shortens to zero. In industrial organisation models, this is not a problem since collusion involves prices (or quantities) that are hard to observe; prices are often in private contracts struck between one producer and her customers, neither of which has an incentive to reveal the information to the other producers. By contrast, this is the fatal flaw of the self-enforcing tariff agreement models as the non-detection period is basically a matter of hours. ${ }^{6)}$ Foreign companies who pay the deviation-tariff know

5) Self-enforcing tariff liberalisation models were first explained by Dixit (1987) and Jensen and Thursby (1984) and extended brought to the attention of the wider community of academic trade economists by the famous Bagwell and Staiger (1990) article.

6) For example, the surprise announcement of a 10\% US tariff hike on 15 August 1971 was made on national television by President Nixon; the nightly news coverage included the reaction of European and Japanese policy makers. The nondetection period was zero; deviation was detected even before the deviation tariff was applied. 
about it immediately and have an incentive to report it to their own government who can then implement the punishment strategy at the stroke of a pen. Thus $\delta$ essentially equals unity in tariff games. This means that selfenforcing tariff agreement models - such as Coates and Ludema (2001) - cannot account for tariff cooperation, i.e. $(1-\delta)\left(\mathrm{W}^{\mathrm{d}}-\mathrm{W}^{\mathrm{n}}\right)=0$. Some other approach is needed.

Ludema, Mayda and Mishra (2010) develop a sophisticated model whereby firms influence the government's tariff choices by transmitting information about the value of protection by means of cheap-talk messages and costly lobbying. They apply this to a particular form of temporary unilateralism in the US known as 'tariff suspensions'.

This model does not help us understand the mass shift to unilateralism discussed above as it fails to tackle the paradox of liberalisation, i.e. why it would be politically optimal to remove a tariff that was previously politically optimal to impose. The model opens with an exogenously set tariff on an intermediate good; in the first period the government may decide to rescind the tariff, and the heart of the model lies in the political competition between upstream and downstream firms. But if rescinding the tariff is politically optimal in period one, why is the tariff imposed in the first place?

Krishna and Mitra (2008) present an appealing account of the basic political economy forces behind unilateral tariff cutting, or more specifically of 'reciprocated unilateralism' whereby a unilateral tariff liberalisation by one nation triggers unilateral tariff liberalisation in another. When both nations' trade policies are determined endogenously, multiple equilibriums arise; either both liberalise or neither do. The basic logic can be thought of as picking up half way through the juggernaut effect; instead of trade talks triggering a reciprocal tariff cut that then induces industrial restructuring which in turn sets the scene for further tariff cutting, this model starts the juggernaut rolling with an autonomous foreign tariff cut.

In the Krishna-Mitra model, a nation's tariff is the outcome of a domestic struggle between pro-unilateralliberalisation interests in the export sector (they want to lower the cost of imports) and anti-unilateral-liberalisation interests in the import-competing sector. If a nation's trade partner removes its tariffs unilaterally, the additional foreign market access shifts economic resources from the pro-tariff group to the anti-tariff group. As political power is linked to a sector's economic size, the result is unilateral liberalisation of a type that might be called 'contagious' unilateralism. This insightful logic is very appealing and almost surely plays an important role in understanding some aspects of the observed unilateral tariff cutting. For example, it explains how shifted political power among domestic special interest groups can make a low-tariff equilibrium self-enforcing without relying on the flawed self-enforcement approach discussed above.

There are, however, a couple of difficulties in using this analytic framework to understand the facts discussed above. The first concerns timing. The rich nations - whose markets are the main destination for developing nation exports - lowered their tariffs progressively from 1948, with major steps in the 1950s, 1960s (Kennedy Round), and 1970s (Tokyo Round), and 1990s (Uruguay Round); see Figure 3 for the facts for the US, which are broadly in line with those of the EU and Japan (imports of these three accounted for over 70\% of world imports up to 1995).

Presuming that Krishna and Mitra (2008) have in mind this sort of GATT-driven liberalisation by rich nations 
that was extended unilaterally to developing nations according the most favoured nation principle, we have a problem. The timing of the unilateral cuts in developing nations does not match the timing of the rich nations' cuts.

The general point is clear in Figure 1, and in the more detailed series that are shown for Latin America and East Asia in Figure 4. In both regions, there is substantial variation among nations, but a clear general towards unilateral tariff reduction. From the mid 1980s in Latin America and from the mid to late 1980s in East Asia, most of the nations started lowering tariffs rapidly. The unilateralism in Latin American came a bit earlier and happened more rapidly than it did in East Asia, but it did not proceed as far. Most Latin American tariff averages steadied at about $10 \%$, while most in East Asia were below 5\% by 2000.

This is the timing problem. The major MFN tariff cutting in the advanced economies occurred in the late 1960s and 1970s. As the developing nation unilateralism started a decade later, it is somewhat strained to view rich-nation tariff cutting in the GATT Rounds as the main trigger of developing-nation unilateralism.

Another line of reasoning that surely is part of the complete story of global unilateralism concerns 'spillover' effects from reciprocal liberalisation. Two economic mechanisms have been highlighted in the literature that link preferential liberalisation done in reciprocal RTAs to unilateral MFN liberalisation. The first links RTAs to unilateral MFN liberalisation. The second looks at how a RTA can lower or raise a nation's 'effective' MFN tariff rate.

The first approach was motivated by the Latin American experience where regional tariff cutting was accompanied by unilateral MFN tariff cutting. As Figure 5 shows, the time path of reciprocal tariff cutting in the many Latin American RTAs bears a striking resemblance to the time path of MFN unilateralism shown in Figure 4. The question that structures this literature is: What is the impact of an RTA on a nation's unilaterally optimal MFN tariff - Intuitively, the answer turns on whether preferential tariffs are "political" complements or substitutes for MFN tariffs.

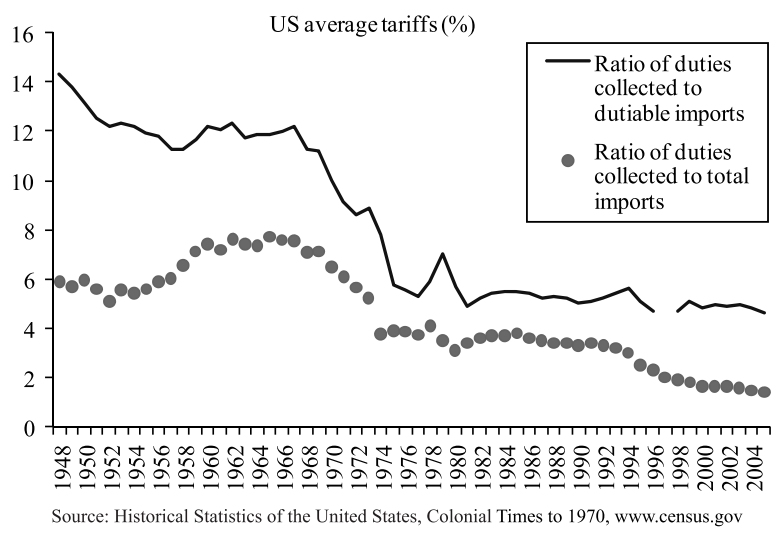

Figure 3 US tariff reductions, 1948 to 2005. 

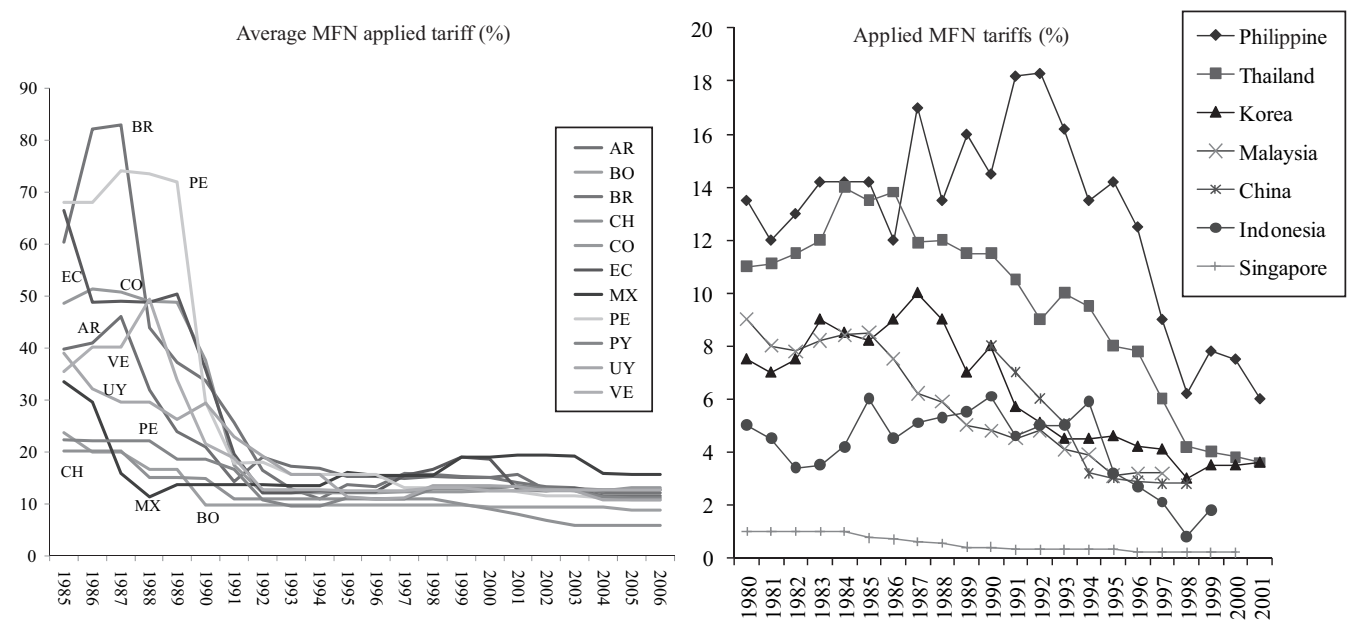

Source: IADB and ITC database.

Figure 4 Applied MFN tariff liberalisation in Latin American and East Asia.

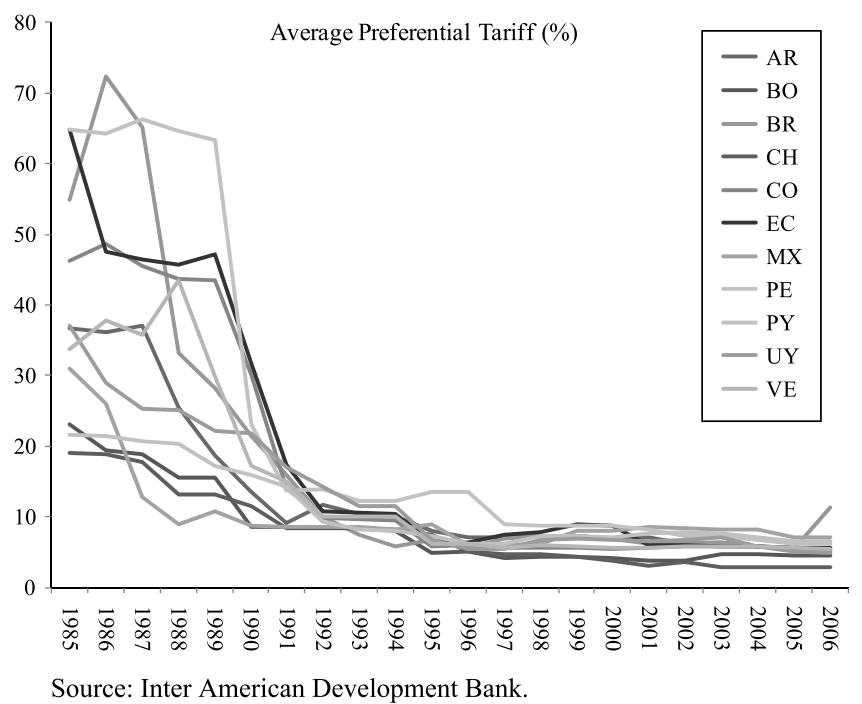

Figure 5 Average preferential tariffs in Latin America, 1985 - 2006.

The easiest way to organise the various mechanisms is to start from Meade's formula for the welfare impact of any trade policy change in a Walrasian economy, namely TdM minus Mdp* where T is the specific tariff vector, M is the bilateral import matrix, and p* is the border price vector (see Baldwin and Venables 1995). A nation choosing its bilateral tariffs optimally would view this as a first order condition and set it to zero to find its optimal tariff. The optimal bilateral tariffs are $T_{o d}=M_{o d}\left(\frac{d p^{*}}{d M_{o d}}\right)$, where 'o' indicates the origin nation and 'd' the destination nation (i.e. the nation choosing the tariffs). In general, anything can happen to $\mathrm{T}_{\mathrm{od}}$ when the nation signs a free 
trade agreement since - according to the Slutsky equation - the direct and cross-good income and substitution effects of the FTA-induced price changes could raise or lower the right-hand side. Attempts to resolve the inherent ambiguity have led to several economic mechanisms being stressed in the literature.

The first mechanism turns on the general principle that taxes become more distortionary when the cross-product variance of rates increases. Bilateral tariff cutting linked to an RTA increases the variance of tariffs across a nation's suppliers of imports. This increases inefficiency and creates an efficiency-based argument for reducing tariffs on third-nation imports, i.e. for unilateralism. Ornelas (2005a) makes the point very cleanly in a Brander-Krugman model of two-way trade with three nations, but the argument would go through in a wider class of models. Taking the RTA implementation as exogenous, the RTA-induced price changes typically reduce RTA members' trade with third nations (trade diversion). If the slope of the import supply curve from third nations is not increasing too fast, the reduction in $\mathrm{M}_{\mathrm{od}}$ will bring down the optimal $\mathrm{T}_{\mathrm{od}}$ for third nations, i.e. induce unilateral MFN liberalisation. Richardson (1993) presents a related argument that focuses on tariff revenue losses. Ornelas (2005b, c) make a similar argument that links MFN unilateralism to the exogenous implementation of an RTA. As preferential tariff cutting typically undermines the import competing industry to some extent, it also undermines political demand for tariffs on third-nation imports. This induces the government to re-optimise external tariffs in a downward direction. Other contributions in this line include Estevadeordal et al. (2008), Calvo-Pardo et al. (2009).

Conconi and Perroni (2010), a paper that was still in draft form when this article went to press, relies on a Krishna-Mitra-like mechanism to explain why unilateralism might be contagious. That is, foreign liberalisation shifts resources out of the import-competing sector in equilibrium and this makes it easier for the home government to sustain unilateral free trade. Specifically, Conconi and Perroni (2010) work with the asymmetric lobbying set-up of Baldwin and Robert-Nicoud (2002) where entry eliminates quasi-rents and thus all incentives to lobby whenever tariffs are constant over time. To this they add a credibility problem whereby the government has an incentive to raise the tariff by surprise as a means of temporarily creating quasi-rents in the import-competing sector. As the size of the temporary quasi-rents increases with the pre-surprise size of the import-competing sector, and this size is reduced by foreign tariff liberalisation (due to the Krishna-Mitra-like resources shift), foreign unilateral tariff liberalisation tends to make it easier for the home government to stick to a path of free trade. In this sense, unilateral liberalisation is contagious. However, foreign liberalisation also reduces the difference between the free trade an opportunistic tariffs paths, so foreign liberalisation has an ambiguous impact on the sustainability of free trade.

More specifically, the authors' assumptions generate a standard time-inconsistency problem; the small-country government would like to commit to permanent free trade, but faces a temptation to announce such a policy and then renege. If the free-trade path is credible, free entry implies that there are no rents to lobby for and thus no lobbying; free trade is politically optimal (their government has a Grossman-Helpman protection-for-sale objective function which reverts to the social welfare function when tariffs are constant as per the Baldwin-Robert-Nicoud result). If the free trade path it is not credible, lobbying occurs on the margin so - even though there are no quasi- 
rent in equilibrium - the outcome is a positive, time-invariant level of protection. As this is inferior to the free trade path, the government faces a classic a repeated prisoner's dilemma game. As noted above in the discussion of the Coates-Ludema paper, the 'cooperative' outcome (free trade in this application) is sustained if and only if the one-shot value of deviating is not too much higher than the non-cooperative outcome (permanent protection in this application). In symbols, free trade can be unilaterally sustained when $\mathrm{W}^{\mathrm{c}}$ exceeds $(1-\delta) \mathrm{W}^{\mathrm{d}}+\delta \mathrm{W}^{\mathrm{n}}$. As foreign liberalisation reduces $\mathrm{W}^{\mathrm{d}}$ but raises $\mathrm{W}^{\mathrm{n}}$, the net effect on free-trade sustainability is unclear.

There are three problems in using this political economy logic to understand real world unilateralism. First, the authors do not explore the class of parameterisations leading to the real-world outcome (i.e. small nations embrace unilateral free trade) and they note that standard parameterisations (e.g. linear demand) leads to the rather un-useful result that foreign liberalisation has no impact on domestic liberalisation. Second, the paper does not confront the 'liberalisation paradox' directly, i.e. why nations that previously found it optimal to protect unilaterally now find it optimal to liberalise unilaterally. Third, even if the first two were fixed, the deep fundamentals of the ConconiPerroni mechanism would be those of Krishna-Mitra and thus subject to the timing problem that rich nations liberalised a decade before developing nations.

A very different mechanism is suggested in Baldwin (2006b). This informally sketches the logic of how competition for offshored factories induces developing nations to lower tariffs on parts and components in what might be called 'race to the bottom unilateralism'. Vezina (2010) presents empirical evidence that the race-to-thebottom mechanism was in action in East Asia.

A final line of argumentation in the economics literature - one that is often viewed as explaining unilateralism in Africa and India - is the 'conditionality approach'. This focuses on that fact that the IMF typically used their leverage during crisis-linked interventions to force nations to unilaterally cut tariffs. . The conditionality attached to extending loans frequently requires nations to reduce trade barriers (Stone 2004, Borgatti 2006).

In the International Relations literature, the rise of democracy is often painted as a key driver. For example, Milner and Kubota (2005) argue that democratisation of the political system reduces the ability of governments to use trade barriers as a strategy for building political support.

Discussion in the final section suggests how the new arguments in this paper could be combined with elements of the existing literature to provide an account of real world unilateralism.

\section{Political Economy of Unilateral Trade Liberalization}

Any understanding of trade liberalisation necessarily rests on three pillars (Baldwin and Baldwin 1996). The first explains why the protection removed was politically optimal to start with. The second is a shock that changes the economic and/or political setting. The third explains how the shock makes removing the protection politically optimal.

For most forms of trade liberalisation the first pillar is the easiest - typically some form of "Olson's 
Asymmetry" explains why economically inefficient protection is chosen (Olson 1965). That is, when the winners from protection are politically organised while some of the losers from protection are not, a politically motivated government will typically choose protection that exceeds the welfare maximising level to benefit the organised interest group. When it comes to the unilateral liberalisation of parts and components, however, the first pillar is the hard part.

As it turns out, using the standard protection-for-sale parameterisation of Olson's Asymmetry (the Grossman and Helpman 1994 PFS model), protection on parts and components should not happen - assuming that both final goods firms and parts makers are politically organised. We demonstrate this point directly below, but the basic result has been widely known since Cadot, de Melo and Olarreaga (2004). Anything that raises the price of parts boosts the profits of parts manufactures but lowers the profits of final goods manufactures by as much (if there are no imports) or more (if imports are positive). As a consequence, the government maximises its contributions for any given level of domestic welfare by setting tariff on parts to zero.

In the next section, we introduce two modifications to the PFS approach that explains why protection of parts and components is politically optimal in the first place. Before turning to the models, we introduce notation and fix ideas by demonstrating that the equilibrium tariff on parts is indeed zero in the simple PFS approach.

\subsection{PFS with a domestic supply chain}

To illustrate the basic issues as simply as possible, we work with the standard assumptions of the simplified protection-for-sale (PFS) model and add a stylized supply chain. ${ }^{7)}$ Specifically, we assume a small-open, RicardoViner economy with three sectors (A, the numeraire good, Y, the parts sector, and Z, the final goods sector) and three productive factors (labour and the sector-specific capital employed in the $\mathrm{Y}$ and $\mathrm{Z}$ sectors). Perfect competition and constant returns are assumed for all sectors; A and $\mathrm{Y}$ are made from primary factors while $\mathrm{Z}$ is made from $\mathrm{Y}$ and primary factors. The per-capita indirect utility function is:

$$
e+\sum_{i=1}^{n} s_{i}\left[p_{i}\right]
$$

where $\mathrm{n}$ is the number of non-numeraire sectors, the si is the sub-indirect utility functions for each non-numeraire sector, and 'e' is expenditure. Expenditure equals the sum of labour and capital income.

The government's objective function $\Omega$ is a weighted sum of social welfare $\mathrm{W}$, and lobbying contributions, $\mathrm{C}$ :

$$
\Omega=a W+\sum_{j \in \Lambda} C_{i}\left[p_{i}\right]
$$

where capital lambda, $\Lambda$, is the set of sectors that are organised politically (and thus can make political contributions) and $\mathrm{C}_{\mathrm{i}}$ is the contribution of sector i. Each lobby's contribution schedule is assumed to be 'truthful'

7) The simplifications of the PFS model we exploit are explained in Baldwin and Robert-Nicoud (2006). 
- specifically it is sector operating profits minus a constant that is determined in equilibrium (this assumes that lobbyists ignore price effects beyond their own sector).

We introduce the supply chain by assuming that each final good requires one part as an input in addition to labour. ${ }^{8)}$ We have two nations, Home and Foreign, that compete in both parts (Y) and final goods (Z); but we start by taking Home to be "small", i.e. it takes border prices as parametric. We assume that Home would be an importer of both parts and final goods under free trade. The Home nation has a comparative advantage in the numeraire (untaxed) good. With this, the small open economy assumption pins down the Home wage rate; it must be such that the domestic price of the numeraire good exactly matches the exogenously given world price. Choosing units of the numeraire good, this result allows us to normalise the Home wage to unity (thus wage does not appear explicitly in cost and profit functions).

\subsubsection{Free trade in final goods and parts}

We open the analysis by considering the outcome when all Home tariffs are zero. The left panel shows the supply and demand diagram in the parts market; $S_{Y}$ is the supply curve and $D_{Y}$ is the demand curve. Demand for $\mathrm{Y}$ is derived demand, i.e. it is based on the output of the domestic final sector. The diagram reflects the fact that each unit of the final good $\mathrm{Z}$ requires one unit of $\mathrm{Y}$ and some additional inputs.

The right panel shows the market for the final good, $Z$; the demand curve for $Z$ depends upon consumer optimization in the usual fashion; however the supply curve is linked to the price of parts, Y. Final-goods technology is such that there is a rising marginal cost of turning parts into final goods. This marginal cost curve is shown as MC in the right panel. The supply curve for $Z$ - i.e. the full marginal cost curve - is MC plus the price of $\mathrm{Y}$. That is why the $\mathrm{Z}$ supply curve, $\mathrm{S}_{Z}$, starts at $\mathrm{P}_{\mathrm{Y}}$ where $\mathrm{P}_{\mathrm{Y}}$ is the equilibrium price of parts and rises in line with MC (recall we assume one part is required per final good).

With free trade, the price in the $\mathrm{Y}$ market is set by the world price $\mathrm{P}^{\mathrm{w}}{ }_{Y}$ and so the Home output of $\mathrm{Y}$ is $\mathrm{Q}_{\mathrm{Y}}$ which not tied to $\mathrm{Q}_{\mathrm{Z}}$. The equilibrium in the final good market is altered as the cost of parts is now set at $\mathrm{P}_{\mathrm{y}}{ }^{w}$.

The diagram shows the fundamental tension within the domestic supply chain. Any positive tariff in $\mathrm{Y}$ would help $\mathrm{Y}$ producers but harm $\mathrm{Z}$ producers by even more. Moreover, as domestic $\mathrm{Y}$ production is independent of $\mathrm{Z}$ production, $\mathrm{Y}$ producers have no interest in supporting domestic Z-sector production on the margin.

\subsubsection{Supply chains and tariffs: PFS approach}

The politically optimal tariffs solve the government's two first order conditions (i.e. for the $\mathrm{Y}$ and $\mathrm{Z}$ sectors). Taking account of the non-negativity constraint on tariffs, the government's first order conditions are:

$$
\begin{aligned}
& 0 \geq a\left(N r_{Z}{ }^{\prime}\left[p_{Z}\right]+N s_{Z}{ }^{\prime}\left[p_{Z}\right]+\frac{d \pi_{Z}\left[p_{Y}, p_{Z}\right]}{d p_{Z}}\right)+\frac{d \pi_{Z}\left[p_{Y}, p_{Z}\right]}{d p_{Z}} \\
& 0 \geq a\left(N r_{Y}{ }^{\prime}\left[p_{Y}\right]+N s_{Y}{ }^{\prime}\left[p_{Y}\right]+\frac{d \pi_{y}\left[p_{y}\right]}{d p_{Y}}+\frac{d \pi_{Z}\left[p_{Y}, p_{Z}\right]}{d p_{Y}}\right)+\frac{d \pi_{Y}\left[p_{Y}\right]}{d p_{Y}}+\frac{d \pi_{Z}\left[p_{Y}, p_{Z}\right]}{d p_{Y}}
\end{aligned}
$$

8) For analysis of more complex supply relationships, see Cadot, de Melo and Olarreaga (2004). 


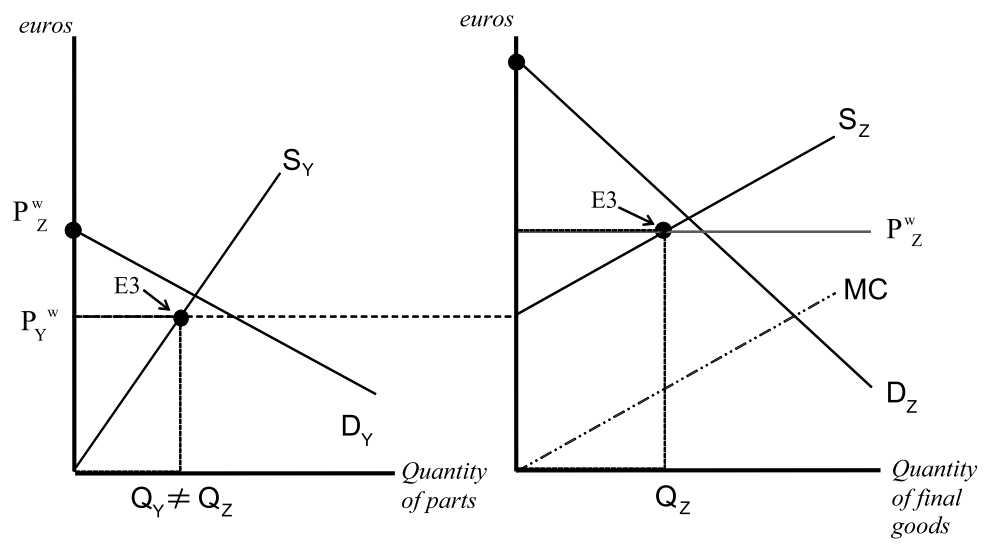

Figure 6 Trade in parts and final goods

Note that, for notational convenience, the choice is with respect to the domestic price rather than the tariff directly; the equilibrium tariff is backed out of the optimal domestic price using the exogenous world price. Here $\mathrm{N}$ is the mass of citizens, and $r_{i}$ and $s_{i}$ are the per capita tariff revenue and consumer surplus functions, and $p$ not-i is sector-i operating profit, i.e. the Ricardian surplus that is the reward to the sector specific capital.

By direct calculation and the envelope theorem:

$$
N r_{i}{ }^{\prime}\left[p_{i}\right]=M_{i}+t_{i} \frac{d M_{i}}{d p_{i}} ; N s_{i}{ }^{\prime}\left[p_{i}\right]=-D_{i} ; \frac{d \pi_{y}}{d p_{y}}=Q_{y} ; \frac{d \pi_{z}}{d p_{y}}=-Q_{z} ; \frac{d \pi_{z}}{d p_{z}}=Q_{z}
$$

where $M_{i}, D_{i}$, and $Q_{i}$ are sector-i imports, demand, and domestic production respectively; $d M_{i} / d p_{i}$ is the change in imports in response to a domestic price change. Using these relationships to simplify the first order conditions, we have:

$$
0 \geq a t_{Z} \frac{d M_{Z}}{d p_{z}}+Q_{Z} ; \quad 0 \geq a t_{Y} \frac{d M_{Y}}{d p_{Y}}-M_{Y}
$$

The first expression says that the politically optimal $t_{\mathrm{Z}}$ is positive. That is, as the first term is negative (due to $\left.\mathrm{dM}_{\mathrm{i}} / \mathrm{dp}_{\mathrm{i}}<0\right)$ and the second term is positive $\left(\mathrm{as}_{\mathrm{z}}>0\right), \mathrm{t}_{\mathrm{z}}$ must be positive for the sum to be zero. The second expression says that the equilibrium $t_{\mathrm{y}}$ is zero; both terms are negative for any positive value of $t_{y}$, so complimentary slackness tells us that the corner solution is the answer.

The intuition for these results is simple; Olson's asymmetry applies to final goods but not to parts. The whole logic of protection in the PFS approach is to transfer income from unorganised interest groups to organised ones. This requires that some of the losers from protection are unorganised politically - a fact that means their interests get underweighted by policy makers. Tariffs on parts are zero because both parts and final good producers are organised, so free trade in parts is best both for social welfare and the government. Tariffs on final goods are positive as the losers from $\mathrm{t}_{\mathrm{z}}>0$, i.e. consumers, are not organised politically. 


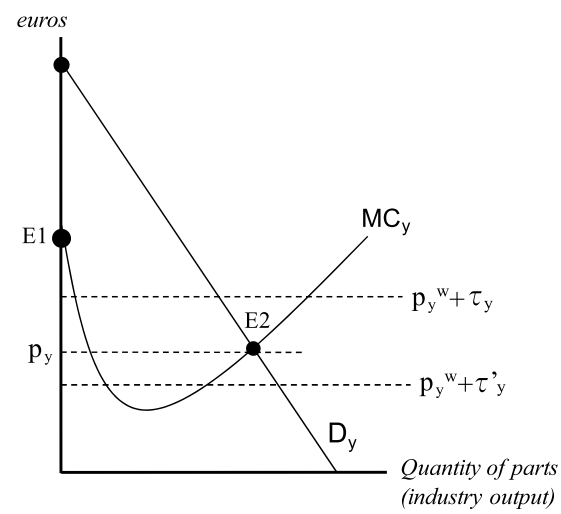

Figure 7 Multiple equilibrium in the parts market with external economies

\section{Unbundling and Unilateral Trade Liberalization: Two Models}

The Cadot, de Melo and Olarreaga (2004) tariff escalation result - which we illustrated in the previous section in a simple model - implies that some additional elements must be added to the standard lobbying model to account for the observation that so many developing nations protected both parts and final goods as part of their infantindustry trade policies. In this section, we sketch out two modifications that could account for the initial protection of parts and its subsequent removal induced by an unbundling-related shock.

\subsection{Infant industries and price-lowering protection}

The first model explains the initial protection by introducing an economic mechanism that implies that Home protection of parts can lower the domestic price of parts. The mechanism is scale economies in a setting where import-substitution polices make economic sense.

If parts production is subject to economies of scale, local production is only economic if it takes place on a sufficiently large scale. If the scale economies are external to the firms, multiple equilibria can arise. Without a sufficiently high tariff on parts, there would be little domestic parts production and marginal production costs would be high forcing domestic final goods producers to import parts. A tariff on parts stimulates domestic production and thus lowers domestic costs and prices for parts. In such a setting, lobbying for a tariff on parts is lobbying for lower priced parts, not higher priced parts.

The model embraces all the assumptions of the PFS model in Section 3.1 with one exception. Parts production is still marked by constant returns at the firm level but now we introduce external economies at the industry level. The $\mathrm{Y}$ and $\mathrm{Z}$ sector technologies are reflected in the cost and profit functions $\mathrm{C}_{\mathrm{z}}\left[\mathrm{p}_{\mathrm{y}}, \mathrm{z}\right], \mathrm{C}_{\mathrm{y}}[\mathrm{y}, \mathrm{Y}], \Pi_{\mathrm{z}}\left[\mathrm{p}_{\mathrm{z}}, \mathrm{p}_{\mathrm{y}}\right]$, and $\Pi_{\mathrm{y}}\left[\mathrm{p}_{\mathrm{y}}, \mathrm{Y}\right]$ where lower-case $\mathrm{y}$ and $\mathrm{z}$ represent firm-level output while their upper-case correspondents represent industry-level output. As usual, profits are increasing in the firm's own price and decreasing in the price of inputs. 


\subsubsection{Parts protection and multiple political economy equilibriums}

We start from the initial situation where tariffs are zero and domestic parts production is zero. We assume that the external economies are such that domestic parts production is uncompetitive in this situation. Specifically, marginal costs in $\mathrm{Y}$ evaluated at $\mathrm{Y}=0$ exceed $\mathrm{p}_{\mathrm{y}}{ }^{w} \mathrm{~W}+\tau_{\mathrm{y}}$, where $\mathrm{p}_{\mathrm{y}}{ }^{w}$ is the world price of $\mathrm{y}$ and $\tau_{y}$ is the frictional trade barrier. Here frictional trade barriers are meant to capture all the difficulties involved in buying parts from distant suppliers, e.g. coordination costs, problems with unpredictable delivery delays, and shipping costs. The situation is shown in Figure 7 at point E1.

To consider the political economy around E1, we suppose that the Home Z industry takes this situation as given - more precisely, it believes that its actions can only move the equilibrium in the neighbourhood of E1. In this case, it will lobby for tariffs in its own sector but against tariffs on $\mathrm{Y}$ and - as we saw above - the result will be a positive $\mathrm{Z}$ tariff, but a zero $\mathrm{Y}$ tariff. This, however, is not the only conceivable outcome. The presence of external scale effects means that protection of domestic parts production may actually lower the domestic price of parts.

If the firm-level marginal cost of production in Y falls initially as industry output expands, it is possible that there is a second stable equilibrium, E2, where domestically produced parts are cheaper than imports. If $Z$ sector understands the presence of external economies, they would lobby for a prohibitive tariff in parts in order to shift the outcome from E1 to E2. This, of course, is just the sort of economic setting in which import-substitution policies make sense economically.

More formally, we characterise the government political economy choice under the two outcomes. In the standard PFS set up, the domestic price $p_{y}$ varies smoothly with the tariff on $y$, specifically $p_{y}=p_{y}{ }^{w}+\tau_{y}+t_{y}$. In the current situation, however, there is a discontinuity in the formula, $\mathrm{p}_{\mathrm{y}}=\mathrm{p}_{\mathrm{y}}{ }^{w}+\tau_{\mathrm{y}}+\mathrm{t}_{\mathrm{y}}$. When $\mathrm{p}_{\mathrm{y}}<\mathrm{p}_{\mathrm{y}}{ }^{w}+\tau_{y}$, changes in ty have no effect on $\mathrm{p}_{\mathrm{y}}$. This requires us to look directly at the government's tariff choice. Doing this, the government's first order condition for $t_{\mathrm{y}}$ is:

$$
0 \geq a\left(N r_{Y}{ }^{\prime}\left[p_{Y}\right]+N s_{Y}{ }^{\prime}\left[p_{Y}\right]+\frac{d \pi_{Y}}{d p_{Y}}+\frac{d \pi_{Z}}{d p_{Y}}\right) \frac{d p_{y}}{d t_{y}}+\left(\frac{d \pi_{Y}}{d p_{Y}}+\frac{d \pi_{Z}}{d p_{Y}}\right) \frac{d p_{y}}{d t_{y}}
$$

In the first situation, $\mathrm{E} 1, \mathrm{dp}_{\mathrm{y}} / \mathrm{dt}_{\mathrm{y}}=1$ and $\mathrm{Z}$ firms do not take account of external economies in the $\mathrm{Y}$ sector. Consequently, the politically optimal Y tariff is zero. In the E2 situation, dpy/dty $=0$ as the government's choice of $\mathrm{Y}$ tariff has no impact on domestic Y prices (i.e. there are no imports). What this means is that the first order conditions could be satisfied at $\mathrm{E} 1$ with $\mathrm{t}_{\mathrm{y}}=0$, or at $\mathrm{E} 1$ with $\mathrm{t}_{\mathrm{y}}$ being prohibitive. ${ }^{9)}$ To select the correct solution, the government has to evaluate its objective function at the two points. As $\mathrm{Z}$ sector profits rise as $\mathrm{p}_{\mathrm{y}}$ falls - and

9) The assumption that the government imposes a prohibitive tariff on parts is somewhat arbitrary. The idea is that in a more fully specified dynamic model, where development of the parts sector took time and the outcome was uncertain, a prohibitive tariff on $\mathrm{Y}$ gives the greatest incentive to private agents to move to E2. 
this for level of $\mathrm{p}_{\mathrm{z}}$ - it is clear that the government would prefer the situation at E2 with positive tariffs in Y.

Notice that even though the domestic price of $\mathrm{y}$ is lower at E2 than the trade-cost-laden price of imports, Home is not competitive in the world market as it too faces the frictional trade cost $\tau_{y}$.

\subsubsection{The second unbundling and unilateral liberalisation}

As discussed in the introduction, reductions in the cost of organising complex activities at distance fostered the unbundling and geographic dispersion of manufacturing production. We parsimoniously capture these changes in the model by lowering the frictional trade costs for parts, i.e. $\tau_{y}$.

Given the logic supporting the protectionist outcome E2, it is clear that small reductions in $\tau_{\mathrm{y}}$ need not have any effect on the equilibrium $\mathrm{t}_{\mathrm{y}}$. However once $\tau_{y}$ falls to the point where parts can be bought more cheaply abroad than domestically, the correlation of $\mathrm{Y}$ and $\mathrm{X}$ sector interests disappears and we revert to the Section 3.1 logic where $\mathrm{t}_{\mathrm{y}}=0$ while $\mathrm{t}_{\mathrm{z}}>0$. For example it falls to $\tau_{\mathrm{y}}^{\prime}$ as shown in Figure 7 , any tariff on $\mathrm{Y}$ will help Y-firms while harming Z-firms. As we saw in the initial analysis, this means that the political economy equilibrium reverts immediately to free trade in Y.

This is a story where the underlying shock that fosters international trade in parts also triggers a political economy response that results in a complete unilateral liberalisation of tariffs on parts.

\subsection{The 'development state' and offshoring industrialisation}

The PFS model - with its profit-based lobbying - is not the only reasonable model of government choices when it comes to trade policy. Many developing nation governments seem largely interested in fostering industrialisation per se. A common label for this is the "development state" - a term introduced by the political scientist Chalmers Johnson (Johnson 1982). The second of model linking unbundling to unilateral liberalisation embraces a modified version of the PFS model that has strong 'development state' features. We assume that - as in the PFS model the government chooses trade policy to maximise a modified social welfare function. However the modification involved industrial value added rather than industrial operating profits. Specifically:

$$
\Omega^{d}=a W+\sum_{j \in \mathrm{I}} V_{i}\left[p_{i}\right]
$$

where $\mathrm{V}_{\mathrm{i}}$ is the value added in $i$ at world prices, and $\mathrm{i}$ is the set of industrial sectors. ${ }^{10)}$

To streamline the analysis we work with the economy as described in the previous model, so the objective function is $\Omega^{d}=a W+\left(p_{z}^{w}-p_{y}^{w}\right) S_{z}+p_{\mathrm{y}}{ }^{w} S_{\mathrm{y}}$, where the $\mathrm{S}_{\mathrm{i}}$ are the supply functions of $\mathrm{Y}$ and $\mathrm{Z}$. Note that the supply of $Z$ depends upon $p_{z}-p_{y}$ while the supply of $Y$ depends on $p_{y}$. Before studying the solution to the government's

10) The specification of such government objective functions is necessarily somewhat arbitrary as it is not linked to individual optimization. The choice of using industry value added at world prices is directed by computational convenience, but the basic results would, I conjecture, go through with an objective function that define industry in terms of employment or industrial value added at domestic prices. 
maximisation problem, note that a simple rearrangement of the objective function yields: $\Omega^{d}=a W+p_{z}^{w} S_{z}-p_{y}^{w} M_{y}$ since $\mathrm{M}_{\mathrm{y}}=\mathrm{S}_{\mathrm{z}}-\mathrm{S}_{\mathrm{y}}$. In this form, it is clear that the development state has a much greater intrinsic interest in limiting the import of parts than the PFS government.

Choosing tariffs via domestic prices, the government's first order conditions are:

$$
\begin{aligned}
& 0 \geq a\left(N r_{Z}{ }^{\prime}\left[p_{Z}\right]+N s_{Z}{ }^{\prime}\left[p_{Z}\right]+\frac{d \pi_{Z}}{d p_{Z}}\right)+\left(p_{z}{ }^{w}-p_{y}{ }^{w}\right) \frac{d S_{Z}}{d p_{Z}} \\
& 0 \geq a\left(N r_{Y}{ }^{\prime}\left[p_{Y}\right]+N s_{Y}{ }^{\prime}\left[p_{Y}\right]+\frac{d \pi_{Y}}{d p_{Y}}+\frac{d \pi_{Z}}{d p_{Y}}\right)+\left(p_{z}{ }^{w}-p_{y}^{w}\right) \quad \frac{d S_{Z}}{d p_{y}}+p_{y}{ }^{w} \frac{d S_{y}}{d p_{y}}
\end{aligned}
$$

which, using the standard cancellations and the definition of $\mathrm{M}_{\mathrm{y}}$, can be written as: ${ }^{11)}$

$$
\begin{aligned}
& 0 \geq a t_{z} \frac{d M_{z}}{d p_{z}}+\left(p_{z}{ }^{w}-p_{y}{ }^{w}\right) \frac{d S_{z}}{d p_{z}} ; \\
& 0 \geq a t_{Y} \frac{d M_{Y}}{d p_{Y}}+p_{z}{ }^{w} \frac{d S_{z}}{d p_{y}}-p_{y}{ }^{w} \frac{d M_{y}}{d p_{y}}
\end{aligned}
$$

The tariff chosen in $\mathrm{Z}$ will be positive for the usual reasons (although likely to be lower than in the PFS model as the government cares about value added in $\mathrm{Z}$ rather than profits). The tariff in $\mathrm{Y}$ will be positive as long as $\left(p_{\mathrm{z}}{ }^{w}-p_{\mathrm{y}}{ }^{w}\right) \frac{d S_{z}}{d p_{z}}<p_{\mathrm{y}}{ }^{w} \frac{d S_{y}}{d p_{y}}$ is true. This says that the slope of the $\mathrm{Y}$ supply curve weighted by world prices exceeds the slope of the $\mathrm{Z}$ supply curve weighted by the $\mathrm{Z}$ sector value added at world prices. We presume that holds so $\mathrm{t}_{\mathrm{y}}>0$.

If the government is a pure development state - i.e. it cares only about industrial value added in the sense that the parameter ' $a$ ' is zero - then both $\mathrm{t}_{\mathrm{y}}$ and $\mathrm{t}_{\mathrm{z}}$ will be chosen to be prohibitive. The point is easily seen. If $\mathrm{a}=0$, then the derivatives of $\Omega^{d}$ with respect to the tariffs are everywhere positive, so raising the tariffs raises the objective function. The connection is broken, of course, when all imports cease as at that point tariffs have no further impact on domestic prices.

\subsubsection{Pro-trade FDI and unilateral liberalisation}

Starting from this situation of positive tariffs on parts and final goods, consider the impact of production unbundling on tariffs. Specifically, suppose exogenous changes occur (e.g. the ICT revolution) that allow the offshoring of $\mathrm{Z}$ production by Foreign multinational corporations. We assume this is Grossman-Rossi-Hansberg type offshoring where the multinational brings superior technology with it and so the host-nation's comparative advantage is shifted. That is, they can now combine their superior Z-sector technology with the Home's lowcost labour by building a factory in Home. In principle this could occur in both $\mathrm{Z}$ and $\mathrm{Y}$, but in the spirit of international production unbundling, we focus on the case where it occurs only in $\mathrm{Z}$. This creates a situation where

11) This relies on the fact that $\mathrm{dSz} / \mathrm{dpy}=-\mathrm{dSz} / \mathrm{dpz}-$ a result that stems from the input-output linkages assumed. My thanks to an anonymous referee for point this out. 
Home becomes part of a Foreign-firm's supply chain, importing parts to which it adds value and then exports. ${ }^{12)}$

This exogenous change opens an alternative route to industrialisation. Instead of using barriers to reserve domestic sales for domestic Z-producers, the nation can join an international supply chain and produce $\mathrm{Z}$ for the wider world market.

If the domestic government does allow the offshoring production to be set up in Home, then the nation becomes an exporter of $\mathrm{Z}$ in the case we consider. This of course renders its $\mathrm{Z}$ tariffs useless. More interestingly, it also shifts the endogenous tariff decision in the parts sector in a pro-liberalisation direction.

Recall that pre-offshoring the government balanced the damage that a marginal $\mathrm{Y}$ tariff increase did against the value added it created in Y. The marginal damage consisted of the usual Harberger Triangles (captured by the negative term $a t_{y} \mathrm{dM}_{\mathrm{y}} / \mathrm{dp}_{\mathrm{y}}$ ) plus the marginal reduction in $\mathrm{Z}$ sector output (captured by the negative term $\mathrm{p}_{\mathrm{z}}{ }^{\mathrm{w}} \mathrm{dS}_{\mathrm{z}} / \mathrm{dp}_{\mathrm{y}}$ ). After offshore production of $\mathrm{Z}$ is established and Home's supply curve rotates down to the point where it becomes an exporter, it is clear that the marginal damage to $\mathrm{Z}$ sector value added from any marginal rise is the $\mathrm{Y}$ tariff becomes greater.

For example Figure 8 shows the situation where the tariff on parts has not been modified after the offshoring of $\mathrm{Z}$ production from Foreign to Home has occurred. The question is whether this situation is an equilibrium or whether the Home government would find a lower $t_{\mathrm{y}}$ to be politically optimal after the offshoring. What is clear from the diagram is that any change in $\mathrm{Z}$ sector technology that allows the nation to become an exporter will involve a flatter supply curve in the $\mathrm{Z}$ sector. In other words, $\mathrm{Z}$ production becomes more sensitive to the price of parts and thus the marginal damage from raising $t_{\mathrm{y}}$ is higher at any level of $t_{\mathrm{y}}$. By inspection of the first order conditions, this tells us that the Home government will find it optimal to lower the $\mathrm{Y}$ tariff after the offshoring.

In short, output of the offshored $\mathrm{Z}$ factory is more sensitive to parts prices than was the old Home $\mathrm{Z}$ industry, and this raises the marginal cost of maintaining the same level of $t_{y}$. In this way, the new offshoring factors induce a reduction in domestic tariffs on parts.

\subsubsection{Race to the bottom unilateralism}

The analysis hereto has presumed that Foreign multinationals have no choice in the location of offshored factory. They are either placed in the other nation or stay at home. This affords the Home government a free hand in setting its parts tariffs (presuming that the offshoring factories remained profitable).

If we expand the model and allow multiple 'home' nations, it is clear that the multinational would be in a position to bargain over each nation's tariff on parts. As every reduction in the parts tariff raises its profitability, it would

12) Taking the $Y$ and $Z$ structure literally, this becomes what might be called the 'China' case, i.e. where Home is the assembly location for final goods that are then mostly sold onward to third nations. Alternatively, we can view $\mathrm{Y}$ and $\mathrm{Z}$ as any two adjacent links in a value added chain in which case it is more natural to view $\mathrm{Y}$ as parts and $\mathrm{Z}$ as components used in the manufacture of some final good not specified. Doing this formally would require some modifications to the reasoning as then $\mathrm{Z}$ would not be purchased by Home nation consumers, but the basic results would go through. 


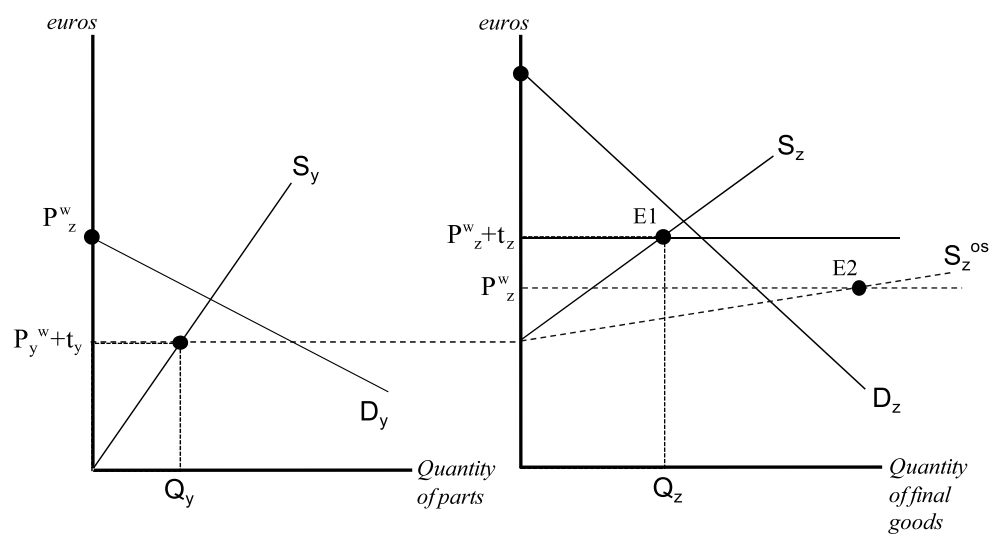

Figure 8 Offshoring and the development state's tariff choices

prefer to locate in a nation with a zero parts tariff. The game is quite analogous to that played by internationally mobile capital and nations that wish to attract it. In the public finance literature, such situations are labelled "race to the bottom" as there is a tendency for governments to lower taxes on mobile factors to zero. Applying the same logic to the model at hand, we see that there will be a tendency for 'home' nations to set their tariffs to zero as a means of attracting offshored factories. Baldwin (2006) calls this "race to the bottom" unilateralism.

\section{Extensions of the Basic Models}

The two models introduced above lay out basic explanations for why production unbundling was associated with unilateral liberalisation. Both fundamentally turn on the reduction in frictional barriers to international commerce. The first focuses on the frictional barriers (including coordination costs) of trade in parts and components. The second focuses on frictional barriers to investment in offshore parts and components production.

In the first model, the trigger of unilateral liberalisation is the lower frictional barriers to organising production in spatially separated facilities. That is, as the cost of coordinating complex activities at distance falls sufficiently, imported parts switch from being more expensive than local parts to less expensive. This returns the setting of the standard PFS situation where free trade in parts is the political equilibrium. In the second, the trigger is the lowering of frictional barriers to what Kojima (1977) called "pro-trade FDI". Here the shock is assumed to affect more than the cost of moving goods across space and coordinating the production process in which they are involved. Here the shock also concerns the economic feasibility of offshoring production from high-wage, high-technology nations to low-wage, low-technology nations while still using the high-wage nation's technology.

In this section, we consider a number of extensions and combinations of the two fundamental political economy mechanisms. 


\subsection{Fragmentation and unilateral liberalisation}

The first extension concerns a pure 'fragmentation' mechanism of the type emphasizeds by Deardorff (1989a, b), Venables (1999), Kohler (2004a), Rodriguez-Clare (2007), Markusen (2006), Antr -s et al. (2006), and most recently Grossman and Rossi-Hansberg $(2006,2008)$. In these models, a sector is initially considered as a single good from the point of view of trade - and presumably - from the political economy perspective. An exogenous change then makes it possible to separate the production stages into two or more segments with trade potentially occurring in the sub-product corresponding to the segments.

In the simplest political economy setting of Section 3.1, such production unbundling will be associated with pressures to reduce the tariff on the upstream parts. To see this, note that the pre-unbundling situation would be like $\mathrm{Z}$ and $\mathrm{Y}$ being merged into one inseparable production process. According to the standard Olson's Asymmetry logic, the government would find it politically optimal to protection the combination as the losers of protection are not organised while the winners are. Unbundling would then shift the situation to the Section 3.1 situation where we saw that the political optimal tariff on the upstream segment, sector Y, is zero. This may help account for the observation that production unbundling is often correlated with unilateral trade liberalisation.

Note that if this occurred, we should observe a densification of the tariff schedule as part of the unilateral liberalisation. That is, as the unbundling occurs, we should see nations defining their tariff lines more narrowly. In the example at hand, the single tariff line applied to the combined $\mathrm{Y}, \mathrm{Z}$ sector would turn into two tariff lines as part of the effort to protection $\mathrm{Z}$ and liberalise $\mathrm{Y}$.

\subsection{Firm-specific parts and components: Export processing}

In the simple models explored in Sections 2 and $4, \mathrm{Y}$ and $\mathrm{Z}$ were homogenous goods in the spirit of the Walrasian models employed. When it comes to manufacturing, however, this is not the only reasonable assumption. For example, seats produced for a particular Toyota sedan do not fit into a local made sedan, say Malaysia's Proton. As it turns out, we can use a combination of the models to study this sort of situation.

To be concrete, consider a three segment supply chain where parts $(\mathrm{X})$ are used in making components $(\mathrm{Y})$ which are used in making final goods (Z). Initially, coordination costs are such that all production segments are bundled in all nations, and we have some production in both Home and Foreign. Furthermore, suppose that Home has poor technology, but compensates for this with low wages.

The shock we focus on is an exogenous change that makes offshoring feasible. Given the wage differences, the advanced nation, Foreign, finds is economically advantageous to offshore the production components to Home as this allows the Foreign firm to combine its advanced technology with low cost labour. However given the firmspecificity of parts, the offshored component factory that is established in Foreign must import all the parts it needs. Moreover, since the components are useless to Home producers of $\mathrm{Z}$, all the output of the offshored industry is exported. 
What happens to tariffs in reaction to the offshored factory - The imported parts pose no threat to the local parts producers so a tariff would bring no political benefits (apart from the tariff revenue) and raising the tariff would actually harm the production of offshored components. If the local government cares a lot about industrial jobs and not very much about tariff revenue, the politically optimal tariff on Foreign parts is zero. This is true whether the local government is interested in promoting local industrial employment, value added or profits.

However, what if it is not possible to define the tariff schedule finely enough to distinguish parts destined for the Foreign and domestic component manufacturing? Here the analysis of the role of friction barriers helps sort things out. The specificity of parts can be modelled as a large friction 'barrier' to using Foreign parts in domestic component-making. The analysis in Section 4.1.1 showed that domestic intermediate goods suppliers can be competitive locally even when their fundamental costs are higher. In Figure 7 for example, tariffs are necessary to shift the equilibrium from E1 to E2, but once the economy is at E2, the tariff can be removed. The frictional barrier separating domestic and Foreign parts is sufficient protection to keep the domestic parts competitive in the domestic economy. If we interpret the frictional costs as a measure of parts-specificity, we can see that it is possible that a zero parts tariff could be politically optimal - even if it is not possible to distinguish between domestic and Foreign parts in the tariff schedule. In this situation, the arrival of the offshored components factory could provide the spark necessary to lower the parts tariff.

The basic point is that if the economy starts at E2, removal of the tariff has no impact on domestic production and prices as long as the product-specificity-linked frictional barriers imply that local parts are cheaper for the local $\mathrm{Z}$ producers than imported parts. Tariffs on components are irrelevant to the offshored production of components as they are all exported, so whatever tariff was optimal previously continues to be after the offshoring.

\subsection{Switch in government type}

Many accounts of unilateral tariff liberalisation in the international relations literature stress the importance of ideas. As the political scientist Razeen Sally puts it: “... practical observation teaches us that the prevailing climate of ideas, interacting with interests and events, can entrench or sway this-or-that set of policies. A policy consensus on import-substitution, state planning and foreign aid was strongly embedded in developing-country governments and international organisations up to the 1970s. ... This set of ideas was overturned by what came to be called the Washington Consensus, which reflected sea-changes in political ideology and in development economics." (Sally 2008).

It is easy to capture such effects by combining our formal models. If a government starts with a 'development state' objective function as in Section 4.2 but switches to a PFS objective function as in Section 3.1, it will find it politically optimal to remove tariffs that it previously found optimal to impose. Less radically, the government could start with a development state objective function and raise the weight it places on social welfare, i.e. the ' $a$ ' parameter. 


\section{Dual Trade Development and the Death of Import Substitution}

The final stylised fact that we wish to address is the fact that import substitution seems to have disappeared as a viable development strategy at approximately the same time as the second unbundling got going in manufacturing. Here we present the outlines of a model that suggests the two are related. We consider a model in which production unbundling per se renders import substitution policies ineffective. This is relevant to unilateral liberalisation since developing countries' a rather rapid turnaround on the merits of industrial tariffs is very much associated with a switch in industrialisation strategy.

For example, countries in East Asia have long followed a dual-track industrialisation strategy (Ando and Kimura 2005). On one hand, they pursued import substitution in an effort to create industries via import protection. On the other hand, they encouraged export platforms that employed their workers to produce goods for exports - often employed direct or indirectly by multinationals. As the 1980s and 1990s proceeded, the classic import substitution track failed increasing while the export-oriented track increasingly succeeded.

The model presented here shows how the offshoring-track renders the import-substitution track less viable. The basic story is that the widespread offshoring of labour-intensive tasks lowers the marginal cost for Foreign final goods and this makes it harder for the developing country to compete in the final good market. The essential claim of the model is that the export oriented strategy led to global effects that rendered the old-fashioned import protection uneconomic.

\subsection{The model}

The basic model is that of Chapter 2.5 in Baldwin et al (2003), which is itself based on the 'footloose capital' model of Rogers and Martin (1995). There are two regions, two sectors, and two productive factors. The regions are symmetric in terms of tastes, but may differ in terms of technology and openness to trade. The two sectors are referred to as industry and agriculture. Industry is marked by increasing returns, monopolistic competition and iceberg trade costs. The agricultural sector is assumed to produce a homogeneous good under Walrasian conditions (constant returns and perfect competition) and its output is traded costlessly. Assuming that both nations produce some $\mathrm{A}$ in equilibrium, this will equalise prices and thus indirectly connect wages in the two nations. That is, $\mathrm{w}^{*} \mathrm{a}_{\mathrm{A}} *=\mathrm{p}_{\mathrm{A}}=\mathrm{wa}_{\mathrm{A}}$, where the $\mathrm{w}$ and $\mathrm{w}^{*}$ are northern and southern wages (southern variables are indicated with an asterisk), and $\mathrm{a}_{\mathrm{A}} *$ and $\mathrm{a}_{\mathrm{A}}$ are the respective unit labour input coefficients. With this, we see that the high technology nation (south) will have a higher wage measured in units of the numeraire, viz. $w^{*} / \mathrm{w}=\mathrm{a}_{\mathrm{A}} / \mathrm{a}_{\mathrm{A}} *>1$.

The productive factors are physical capital $\mathrm{K}$ and labour $\mathrm{L}$, with $\mathrm{K}$ being international mobile while labour is immobile. As capital owners are immobile across regions, physical capital moves but all of its reward is repatriated to its country of origin. Worldwide supplies of capital and labour are fixed, with the world's endowment denoted as $\mathrm{L}^{\mathrm{W}}$ and $\mathrm{K}^{\mathrm{W}}$. 
Because physical capital can be separated from its owners, the region in which capital's income is spent may differ from the region in which it is employed. We must therefore distinguish the share of world capital owned by northern residents (we denote this as $\mathrm{s}_{\mathrm{K}} \equiv \mathrm{K} / \mathrm{K}^{\mathrm{W}}$ ) from the share of world capital employed in the north. Because each industrial variety requires one unit of capital, the share of the world capital stock employed in a region exactly equals the region's share of world industry. Consequently, we can use north's industry share, i.e. $s_{n} \equiv n /(n+n *)$, to represent the share of capital employed in the north and the share of all varieties made in the north.

The cost function of a typical industrial firm in the FC model is non-homothetic; that is to say, the factor intensity of the fixed cost differs from the factor intensity of the variable cost. To keep things simple, we make the extreme assumption that the fixed cost involves only capital and the variable cost only involves labour. More specifically, each industrial firm requires one unit of $\mathrm{K}$ and $\mathrm{a}_{\mathrm{m}}$ units of labour per unit of output. The implied cost function is: $\pi+w_{L} a_{m} x$ where $\pi$ and $\mathrm{w}_{\mathrm{L}}$ are the rewards to capital and labour, $\mathrm{a}_{\mathrm{m}}$ is the variable unit input requirement, and $\mathrm{x}$ is firm-level output.

The representative consumer in each region has preferences given by:

$$
V=\frac{E}{P} ; \quad p \equiv p_{A}^{1-\mu}(\Delta)^{-a} ; \quad \Delta \equiv \int_{i=0}^{n^{w}} p_{i}^{1-\sigma} d i, \quad a \equiv \frac{\mu}{\sigma-1}
$$

where, $\mathrm{n}^{\mathrm{w}}$ is the mass (roughly speaking, the number) of industrial varieties available worldwide, $\mu$ is the expenditure share on industrial varieties, and $\delta$ is the constant elasticity of substitution between any two varieties. Also, $\mathrm{E}$ is northern expenditure, $\mathrm{P}$ is perfect price index, $\mathrm{p}_{\mathrm{A}}$ is the price of $\mathrm{A}, \mathrm{p}_{\mathrm{i}}$ is the consumer price of industrial variety $\mathrm{i}$ (the variety subscript is dropped where clarity permits).

The last assumption concerns factor migration. Physical capital moves in search of the highest nominal reward (i.e. measured in terms of the numeraire) rather than the higher real reward (i.e. deflated by a price index) since its income is spent in the owner's region regardless of where the capital is employed. ${ }^{13)}$ Inter-regional factor flows are governed by the ad hoc "migration" equation $\dot{s}_{n}=\left(\pi-\pi^{*}\right)\left(1-s_{n}\right) s_{n}$.

\subsubsection{The 'peripherality point'}

The location of industry in a geography model depends upon relative market size and the degree of domestic and foreign openness (see Baldwin et al, 2003,Chapter 2.5). Here we add a third concern, namely comparative advantage.

A convenient way to study the interaction of all these forces is to calculate the 'peripherality point', i.e. the smallest market size that permits the small/poor nation to attract at least some industry.

To be concrete we consider the north to be the small (poor) nation that is struggling to promote industrial

13) Nominal versus real here means the reward in terms of the numeraire rather than reward in terms of the consumption bundle $\mathrm{C}_{\mathrm{A}}{ }^{1-\mu} \mathrm{C}_{\mathrm{m}}{ }^{\mu}$ 
development when all industry is initially located in the large (rich) south. ${ }^{14)}$ To add an important real world element to the equation, we allow for technology differences by assuming that the ratio of labour input coefficients differs in the two nations. In particular we assume that the north's ratio $a_{m} / a_{a}$ differs from the south's $a_{M}{ }^{*} / a_{A}{ }^{*}$, where the $\mathrm{a}_{\mathrm{i}}$ 's are sectoral unit labour requirements using our standard notation.

With this modification, the rewards to capital are: ${ }^{15}$

$$
\pi=b\left(\frac{s_{E}}{\Delta}+\frac{\phi^{*}\left(1-s_{E}\right)}{\Delta^{*}}\right) \chi ; \pi^{*}=b\left(\frac{\phi s_{E}}{\Delta}+\frac{1-s_{E}}{\Delta^{*}}\right) ; \quad x \equiv\left(\frac{a_{M}}{a_{M}{ }^{*}}\right)^{1-\sigma}
$$

where

$$
\Delta=\chi_{n}^{s}+\phi\left(1-s_{n}\right), \Delta^{*}=\phi^{*} \chi_{n}^{s}+1-s_{n}
$$

and $\chi$ (a mnemonic for comparative advantage) measures comparative advantage with $\chi>1$ indicating a comparative advantage for the north in industry; $\mathrm{sE}$ is the share of world expenditure in the north, and $\phi$ is the free-ness of trade, i.e. it equals $\tau^{1-\sigma}$ where $\tau$ is the iceberg trade cost. Note that $\mathrm{s}_{\mathrm{E}}$, is exogenous as $\mathrm{L}$ is immobile and K's income is repatriated.

Solving the location condition $\pi=\pi^{*}$ for the spatial division of industry, $\mathrm{s}_{\mathrm{n}}$, allowing for differences in size, openness, and comparative advantage, we have:

$$
s_{n}=\frac{\left(\left(1-s_{E}\right) \phi \phi^{*}+s_{E}\right) \chi-\phi}{(\chi-\phi)\left(1-\chi \phi^{*}\right)}
$$

where, as usual, this is only valid for economically relevant shares; if the right-hand side exceeds unity or is less than zero, then sn is one or zero as appropriate.

Although our expressions are general, we will be particular interested in the case where $\chi>1$, i.e. where the small/poor/un-industrialised nation actually has a fundamental comparative advantage in industry. The interest lies in the fact that in a neoclassical model, the small north would always have some industry regardless of trade costs. In an economic geography model, by contrast, market access considerations can allow a pattern of specialisation that contradicts comparative advantage. Furthermore, since wages are equalised yet north has a lower labour input coefficient in industry, the unit cost of industrial production is lower in the north.

To find the peripherality point, we view $\mathrm{s}_{\mathrm{E}}$ as a parameter and search for the $\mathrm{s}_{\mathrm{E}}$ where $\mathrm{s}_{\mathrm{n}}$ is just equal to zero, i.e. where the core-in-the-south is just barely sustained. Solving $s_{n}=0$, we get the critical market size of the rich/northern market to be:

$$
s_{E}^{P}=\frac{\phi}{1-\phi \phi^{*}}\left(\frac{1}{\chi}-\phi^{*}\right)
$$

where $\mathrm{s}_{\mathrm{E}}{ }^{\mathrm{P}}$ is the peripherality point, i.e. the size of the small northern market that implies it has no industry.

14) In New Economic Geography models, real incomes depend upon industrial location and openness. If both countries are equally open, then, as usual, the small country will have less industry and thus a higher price index. In other words, the small country will also be the poor country.

15) Details of the calculation of the peripherality point can be found in Chapter 11.4 of Baldwin et al (2003). 
Since the north's share of industry is increasing in $\mathrm{s}_{\mathrm{E}}$, we know that north will be without industry (i.e. will be the periphery) for any market size that is less than $\mathrm{s}_{\mathrm{E}}{ }^{\mathrm{P}}$.

A particularly salient feature of the peripherality point is that even if the north has a native comparative advantage in industry $(\chi>1)$ - so that the unit labour cost of producing in north is below that of the big south - industry can still be fully concentrated in the south. In other words, this is an example of agglomeration producing a trade pattern that contradicts the pattern predicted by comparative advantage.

The expression for $\mathrm{s}_{\mathrm{E}}{ }^{\mathrm{P}}$ conveniently organises the various forces that foster industrial underdevelopment. By inspection, $\mathrm{s}_{\mathrm{E}}^{\mathrm{P}}$ is decreasing in $\chi$ and in $\phi^{*}$, and increasing in $\phi$. This means that the greater is the north's comparative advantage in manufacturing, the smaller its market must be to sustain peripherality. Moreover protection of the big market (the south in this case) makes location in the small north less advantageous, so higher big-market protection $\left(\mathrm{d} \phi^{*}<0\right)$ allows northern peripherality at a higher northern market size.

\subsection{Dual track interaction: export promotion extinguishes import substitution}

To relate this to the matter at hand, it suffices to note that $\chi$ would - in a more complete and more complex model with intermediate inputs - depend upon the cost of producing those intermediate inputs. If we start from a world where all production is spatially bundled - i.e. both nations must produce all their own intermediate inputs - the expression for the peripherality point is exact. Now suppose that exogenous changes such as the ICT revolution make it feasible to geographically separate the manufacture of some intermediate inputs and the highertechnology southern firms can bring their superior technology with them if they set up factories in the low-wage north. For the south this would look like the offshoring of industrial jobs; for the north it would look like part of their export-oriented development strategy.

The result will be that southern firms will now see the cost of their intermediate inputs fall, while the costs facing northern firms are unchanged. In terms of the model, this will raise $\chi$, i.e. it will exaggerate the native Ricardian comparative advantage enjoyed by south. Given the formula for the equilibrium peripherality point, we see that the offshoring of parts production to the north has worsened prospects for the north's downstream industry. Indeed if the shift in $\chi$ is large enough, the poor north may see its "infant industry" (the downstream industry) completely wiped out. This, of course, is the result we were trying to illustrate.

\subsubsection{Discussion}

While the model used to illustrate this point is rather special - and indeed not fully worked out here - my conjecture is that the basic economic logic is quite robust. Developing nations who participate in the global supply chains of advanced nation manufactures of, say, automobiles, are indirectly making it harder for their final automobile makers to survive. Or to put it differently, the export-oriented development track may have rendered the import substitution track inoperable for all but the largest developing nations. 


\section{Concluding Remarks}

Unilateral tariff liberalisation by developing nations is a curiously universal phenomenon. There has been, however, very little theoretical work to shape our thinking on why this is occurring. This paper is an attempt to redress this lacuna by introducing three novel mechanisms that could account for unilateral tariff liberalisation by developing nations that previously embraced import substitution policies. The particular emphasis is on the role of production unbundling as a trigger of this unilateralism.

One mechanism focuses on the way that reduced frictional barriers to trade in parts and components can undermine the correlation of interests between developing country parts producers and their downstream customers. A second mechanism focuses on the way that Kojima's pro-trade FDI - a critical component of production unbundling - raise the marginal political economy cost of maintain high upstream barriers. The third mechanism works via a more general equilibrium channel. The idea is that developing countries' participation in the supply chains of advanced-nation industries tends to undermine the developing country's competitiveness in final good production. The eroded final-good competitiveness raises the marginal cost of final good protection, so the developing nation government may find it politically optimal to marginally lower final good tariffs. An alternative is to maintain the effective rate of protection on final goods by lowering the tariff on upstream goods. The result could look like a gradual process whereby the local value chain of the 'infant industry' gets trimmed from the upstream to the downstream, thus making import substitution look like an increasingly unsuccessful strategy. In essence, pursuit of the export-processing industrialisation track undermines the infant-industry track. Unilateral tariff liberalisation, however, is an almost universal phenomenon. The novel mechanism presented in this paper applies most naturally to nations that are in engaged in this sophisticated trade, especially those in Factory Asia, Factory North America and Factory Europe. However the autonomous tariff cutting has also occurred in agriculture goods, and a broad range of nations. Table 1 shows the facts for all developing nations that rank among the 50 largest importers in the world in 2009. The first pair of columns shows the bound tariffs - i.e. the tariff ceilings they have agreed to as WTO members. The high bound rates typically reflect the import substitution tariffs of the 1960s and 1970s which were not negotiated down as developing nations did not play reciprocally in the GATT rounds due to the 'special and differential' treatment afforded to them under GATT rules. The fact that the applied rates (i.e. the tariffs actually charged in 2009) are generally far below the bound rates is a good indication of the extent of unilateral tariff cutting.

Accounting for this broad set of facts probably requires a combination of the novel mechanisms highlighted in this paper, but also a series of other logics to explain tariff cutting in agriculture and developing nation not particularly involved in manufacturing. The basic Krishna-Mtira story, that suggests unilateralism is contagious as it shifts resources of other nations into their export sector and out of their import-competing sector, thus weakening protectionists and strengthening mercantilists. It would also seem important to consider the "uniform tax principle" 
Richard Baldwin : Unilateral Tariff Liberalisation

\begin{tabular}{|c|c|c|c|c|}
\hline & \multicolumn{2}{|c|}{ Agricultural goods } & \multicolumn{2}{|c|}{ Non-agricultural goods } \\
\hline & Bound & MFN applied & Bound & MFN applied \\
\hline Hong Kong & 0 & 0 & 0 & 0 \\
\hline Iran & n.a. & 28.9 & n.a. & 25.6 \\
\hline Russia & n.a. & 14.2 & n.a. & 10.2 \\
\hline Ukraine & 11.1 & 13 & 5 & 4.4 \\
\hline China & 15.8 & 15.6 & 9.1 & 8.7 \\
\hline Chinese Taipei & 17.8 & 16.9 & 4.8 & 4.5 \\
\hline Vietnam & 18.5 & 24.2 & 10.4 & 15.7 \\
\hline Saudi Arabia & 20.7 & 7.1 & 10.5 & 4.9 \\
\hline UAE & 25.4 & 7.1 & 13.1 & 4.7 \\
\hline Singapore & 29.1 & 0.2 & 6.3 & 0 \\
\hline Argentina & 32.5 & 10.3 & 31.8 & 11.9 \\
\hline Philippines & 34.7 & 9.7 & 23.4 & 5.7 \\
\hline Brazil & 35.5 & 10.2 & 30.8 & 14.1 \\
\hline Thailand & 42.7 & 25.2 & 25.6 & 8.2 \\
\hline Mexico & 44.2 & 22.9 & 34.9 & 11.1 \\
\hline Indonesia & 47.1 & 8.5 & 35.6 & 6.7 \\
\hline Venezuela & 55.7 & 16.8 & 33.6 & 12.8 \\
\hline Korea & 59.3 & 49 & 10.2 & 6.6 \\
\hline Turkey & 60.1 & 42.2 & 16.9 & 4.8 \\
\hline Malaysia & 83.4 & 14.7 & 14.9 & 8 \\
\hline Egypt & 96.1 & 66.4 & 27.7 & 9.6 \\
\hline India & 114.2 & 32.2 & 34.7 & 10.1 \\
\hline
\end{tabular}

Source: WTO Tariff Profiles, 2009 (on line database); Russia and Iran were not WTO members in 2009 and so have no bound rates.

Table 1 Leading developing importers: Applied and bound tariffs, 2009

that suggests that cutting tariffs selectively raises the variance of the tariff structure and with this, the inefficiency of the status quo tariff structure. This in turn could produce new political pressures to even out the tariff structure by lower tariffs not directly affected by liberalisation mechanism discussed in this paper.

\section{References}

[ 1 ] Ando, Mitsuyo and Fukunari Kimura (2005). "The Formation of International Production and Distribution Networks in East Asia," in T. Ito and A. Rose (eds) International Trade in East Asia, NBER-East Asia Seminar on Economics, Volume 14, pp.177-216.

[ 2 ] Ariu, Andrea and Giordano Mion (2010). "Trade in Services: IT and Task Content”, pdf, http://personal.lse.ac.uk/mion/cadrea.htm.

[ 3 ] Bagwell, Kyle and Robert W. Staiger (1990). “A Theory of Managed Trade," American Economic Review 80(4): pp.779-795.

[ 4 ] Baldwin, Richard (1994). Towards and Integrated Europe, CEPR, London.

[ 5 ] Baldwin, Richard (2006a). "Globalization: The Great Unbundling(s)", Chapter 1 in Globalisation Challenges for Europe, Secretariat of the Economic Council, Finnish Prime Minister's Office, Helsinki, 2006, pp.5-47.

[ 6 ] Baldwin, Richard (2006b). "Managing the Noodle Bowl: The fragility of East Asian Regionalism,” CEPR DP 5561, March. Eventually published in Singapore Economic Review, vol. 53, issue 03, April pp 449-478. 2008.

[ 7 ] Baldwin, Richard (2010). “Understanding the GATT's wins and WTO’s woes”, CEPR Policy Insight No. 49, June.

[ 8 ] Baldwin, Richard and Anthony Venables (1995). "Regional economic integration," Handbook of International 
Economics, in: G. M. Grossman \& K. Rogoff (ed.), Handbook of International Economics, edition 1, volume 3, chapter 31, pp.1597-1644 Elsevier.

[ 9 ] Baldwin, Richard and Frédéric Robert-Nicoud (2002). "Entry and Asymmetric Lobbying: Why Governments Pick Losers," NBER Working Papers 8756, eventually published in Journal of the European Economic Association, vol. 5(5), pp.1064-1093, 2007.

[10] Baldwin, Richard and Frédéric Robert-Nicoud (2008). "A Simple Model of the Juggernaut Effect of Trade Liberalisation", CEP Discussion Papers DP0845, LSE.

[11] Baldwin, Richard and Robert Baldwin (1996). "Alternative Approaches to the Political Economy of Endogenous Trade Liberalization”, European Economic Review 40, 1996, pp.775-782.

[12] Baldwin, Richard and Robert-Nicoud, Frédéric (2006). "Protection for Sale Made Easy," CEPR Discussion Papers 5452.

[13] Baldwin, Robert (1980). "The Economics of the GATT" in Issues in International Economics, edited by Peter Oppenheimer. Stocksfield, England and Boston: Oriel.

[14] Blackhurst, Richard (1979). "Reciprocity in trade negotiations under flexible exchange rates", in John Martin and Alasdair Smith (eds) Trade and Payments Adjustments Under Flexible Exchange Rates, London: Macmillan, 1979.

[15] Borgatti, Lisa (2006). “A New Tariff Database for Selected Least Developed Countries”, HEI Working Paper No: $12 / 2006$.

[16] Cadot, Olivier, de Melo, Jaime and Olarreaga, Marcelo (2003). "The protectionist bias of duty drawbacks: evidence from Mercosur," Journal of International Economics, Elsevier, vol. 59(1), pp.161-182, January.

[17] Calvo-Pardo, Hector \& Freund, Caroline \& Ornelas, Emanuel, (2009). "The ASEAN free trade agreement : impact on trade flows and external trade barriers," Policy Research Working Paper Series 4960, The World Bank.

[18] Campa and Goldberge (1997). "The Evolving External Orientation of Manufacturing Industries: Evidence from Four Countries", Economic Policy Review, Vol. 3, no. 2: pp.53-81.

[19] Coates, D., and Ludema, R. (2001). “A Theory of Trade Policy Leadership”, Journal of Development Economics $65(1)$.

[20] Conconi, Paola and Carlo Perroni (2010). "Conditional versus Unconditional Trade Concessions for Developing Countries", pdf dated September.

[21] Cooper, Richard (1971). "Tariff issues and the Third World", The World Today, Chatham House publication, September.

[22] Dixit, A. (1987) "Strategic aspects of trade policy", in T.F. Bewley (ed) Advances in Economic Theory: Fifth World Congress, New York: Cambridge University Press.

[23] Estevadeordal, Antoni, Caroline Freund, and Emanuel Ornelas (2008). "Does Regionalism Affect Trade Liberalization toward NonMembers -," The Quarterly Journal of Economics, vol. 123(4), pp.1531-1575, November.

[24] Ethier, W. (2002). "Unilateralism in a Multilateral World," Economic Journal, Royal Economic Society, vol. 112(479), pp.266-292.

[25] Feenstra, Robert and Gordon Hanson (1997). “Foreign direct investment and relative wages: Evidence from Mexico's maquiladoras," Journal of International Economics, Elsevier, vol. 42(3-4), pp.371-393, May.

[26] Fugazza, Marco and Frédéric Robert-Nicoud (2010). "The Emulator Effect of the Uruguay Round on US Regionalism," CEP Discussion Papers dp0973.

[27] Garnaut, Ross (1991). Australia: A case study of unilateral trade liberalisation, in J. Bhagwati and H. Patrick, 
Richard Baldwin : Unilateral Tariff Liberalisation

Aggressive Unilateralism: America's 301 Trade Policy and the World Trading System, University of Michigan Press.

[28] Green, Edward and Robert Porter (1984), "Noncooperative Collusion under Imperfect Price Information," Econometrica, 52, pp.87-100.

[29] Grossman, Gene M \& Helpman, Elhanan (1995). “Trade Wars and Trade Talks," Journal of Political Economy, University of Chicago Press, vol. 103(4), pp.675-708, August.

[30] Grossman, Gene M. and Esteban Rossi-Hansberg (2008). “Trading Tasks: A Simple Theory of Offshoring,” American Economic Review, American Economic Association, vol. 98(5), pp.1978-97.

[31] Hillman, Arye and Peter Moser (1992). "Trade Liberalization as Politically Optimal Exchange of Market Access" published in 1996 in The New Transatlantic Economy, Matthew B. Canzoneri, Wilfred Ethier, Vittorio Grilli (eds), Cambridge University Press.

[32] Hummels, David (1999). “Toward a Geography of Trade Costs,” GTAP Working Papers 1162, Center for Global Trade Analysis, Department of Agricultural Economics, Purdue University.

[33] Johnson, Chalmers (1982). MITI and the Japanese Miracle. Stanford, CA: Stanford University Press.

[34] Kimura, Fukunari, Yuya Takahashi, and Kazunobu Hayakawa (2007). "Fragmentation and parts and components trade: Comparison between East Asia and Europe”, The North American Journal of Economics and Finance, Volume 18, Issue 1,1 pp.23-40.

[35] Kojima Kiyoshi (1975), "International Trade and Foreign Direct Investment: Substitutes or Complements," Hitotsubashi Journal of Economics 16: pp.1-12.

[36] Kojima Kiyoshi (1977a), “Transfer of Technology to Developing Countries -Japanese Type versus American Type," Hitotsubashi Journal of Economics 17: pp.1-14.

[37] Kojima Kiyoshi (1977b), Kaigai Chokusetsu Toshi Ron [Theory of Foreign Direct Investment], Tokyo: Diamond.

[38] Kojima, Kiyoshi (1973), “A Macroeconomic Approach to Foreign Direct Investment," Hitotsubashi Journal of Economics 14: pp.1-20.

[39] Kojima, Kiyoshi (2003, 2005, 2006), Ganko-kei Keizai Hattenron [Flying-Geese-Style Economic Growth], vol. 1: Nihonkeizai, Aziakeizai, Sekai keizai [Japanese Economy, Asian Economy, World Economy]; vol. 2: Azia to Sekai no Shinchitsujo [Asia and World in a New Order]; and vol. 3: Kokusaikeizai to Kinyukiko [International Economy and Monetary System], Tokyo: Bunshindo.

[40] Kojima, Kiyoshi and Terutomo Ozawa (1984), "Micro- and Macro-Economic Models of Direct Foreign Investment: Toward a Synthesis," Hitotsubashi Journal of Economics 25 (1): pp.1-20.

[41] Kojima, Kiyoshi and Terutomo Ozawa (1985), "Toward a Theory of Industrial Restructuring and Dynamic Comparative Advantage,” Hitotsubashi Journal of Economics 26 (2): pp.135-145.

[42] Krishna, Pravin and Mitra, Devashish (2008). "Reciprocated unilateralism in trade reforms with majority voting," Journal of Development Economics, Elsevier, vol. 85(1-2), pp.81-93. First circulated 2004 (NBER WP 10826).

[43] Ludema, Rodney, Anna Maria Mayda, and Prachi Mishra (2010). "Protection for Free - The Political Economy of U.S. Tariff Suspensions”, June, EIIT Working Paper.

[44] Martin, P. and C.A. Rogers (1995) “Industrial location and public infrastructure," Journal of International Economics 39, pp.335-351.

[45] Martin, Will and Francis Ng (2004). “A Note on Sources of Tariff Reductions in Developing Countries 1983-2003”, World Bank, 27 October, mimeo.

[46] Milner, Helen V. \& Kubota, Keiko (2005). "Why the Move to Free Trade - Democracy and Trade Policy in the 
Developing Countries," International Organization, Cambridge University Press, vol. 59(01), pp.107-143, January.

[47] Moser, Peter (1990). The political economy of the GATT, University of St.Gallen PhD thesis. St. Gallen.

[48] Olivier Cadot \& Jaime de Melo \& Marcelo Olarreaga (2004). "Lobbying, Counterlobbying, and the Structure of Tariff Protection in Poor and Rich Countries," World Bank Economic Review, Oxford University Press, vol. 18(3), pp.345-366.

[49] Olson, Mancur (1965). The Logic of Collective Action: Public Goods and the Theory of Groups, Harvard University Press, 1st ed. 1965.

[50] Ornelas, Emanuel (2005a). "Trade creating free trade areas and the undermining of multilateralism," European Economic Review, vol. 49(7), pp.1717-1735, October.

[51] Ornelas, Emanuel (2005b). "Rent Destruction and the Political Viability of Free Trade Agreements," The Quarterly Journal of Economics, vol. 120(4), pp.1475-1506, November.

[52] Richardson, Martin (1993). “Endogenous protection and trade diversion.” Journal of International Economics 34, pp.309-324.

[53] Richardson, Martin (2001) "Unilateral Liberalisation in a Multilateral World," University of Otago Economics Discussion Papers No. 0102, February 2001.

[54] Richter, J.H. (1959). “Trends in International Trade: Review Article”, The Quarterly Journal of Economics, Vol. 73, No. 4 (Nov., 1959), pp. 576-595.

[55] Roesseler, Freider (1978). "The rationale for reciprocity in trade agreements under floating currencies", Kyklos, Volume 31, Issue 2, pp.258-274, May.

[56] Sally, Razeen (2008). "Globalisation and the Political Economy of Trade Liberalisation in the BRIICS" pdf draft, http://www.ecipe.org/people/razeen-sally.

[57] Schott, Jeffrey (1996). The World Trading System: Challenges Ahead, Peterson Insitute of International Economics, Washington, DC.

[58] Stone, Randall (2004). "The Political Economy of IMF Lending in Africa”, American Political Science Review Vol. 98, No. 4 November.

[59] Venables, Anthony (1985). "Trade and Trade Policy with Imperfect Competition: The Case of Identical Products and Free Entry," Journal of International Economics 19, (August), pp.1-20.

[60] Venables, Anthony (1987). "Trade and Trade Policy with Differentiated Products: A Chamberlinian-Ricardian Model." The Economic Journal, 97, pp.700-717.

[61] Vezina, Pierre-Louis (2010). "Race-to-the-bottom tariff cutting" HEID Working Paper No: 12/2010

[62] Young, Soogil (1996). "Political Economy of Trade Liberalization in East Asia", in Jeffery I. Schott (ed.), The World Trading System: Challenges Ahead. Washington D.C.: Institute for International Economics.

[63] Zeiler, T. W. (1997). “GATT Fifty Years Ago: U.S. Trade Policy and Imperial Tariff Preferences", Business and Economic History, Volume 26, no.2, Winter. 